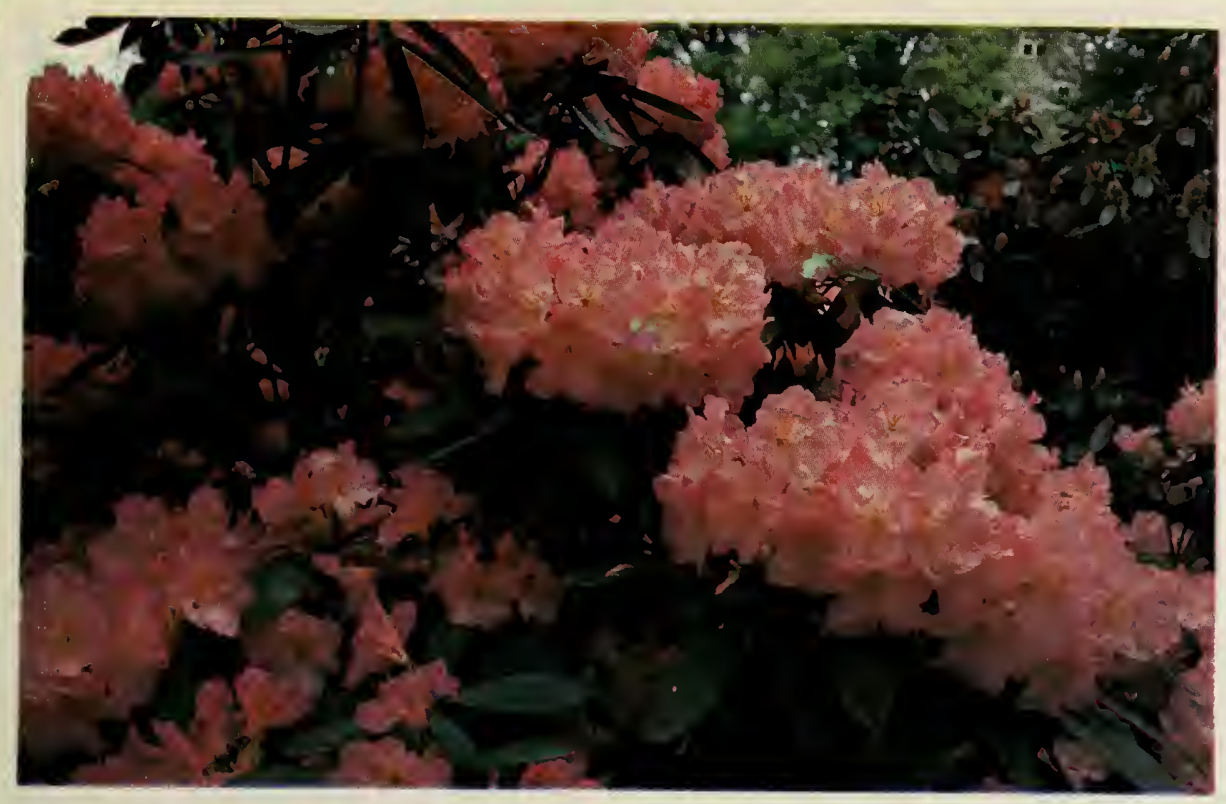

rhododendrons
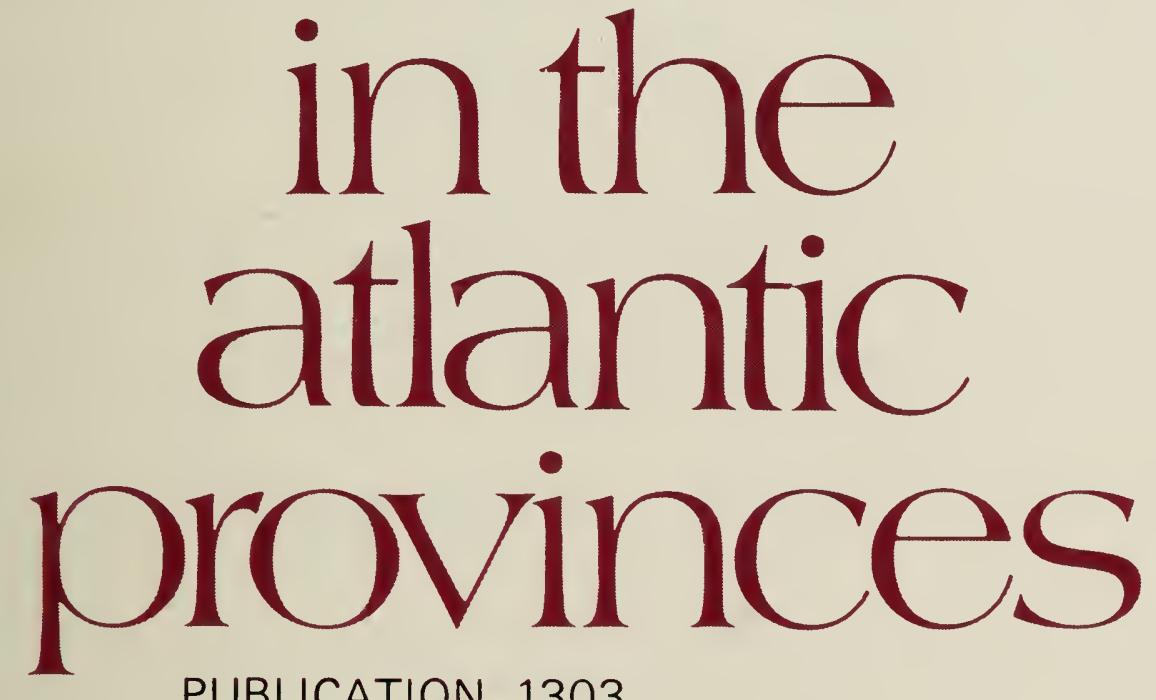

PUBLICATION 1303

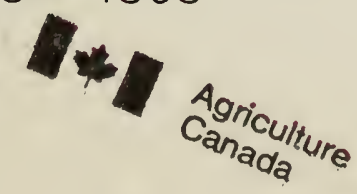

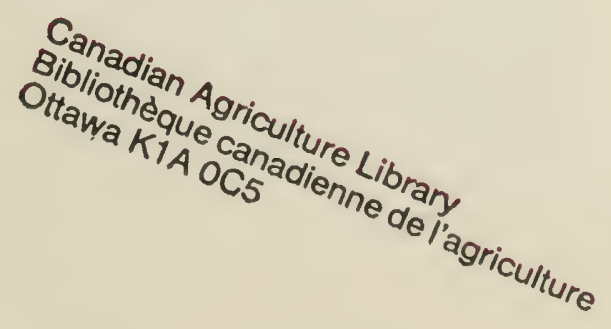

$630 \cdot 4$

C212

P/303

Ath Ágriculture ${ }^{c} 3$.

Canada 
PUBLICATION 1303, available from

Information Services, Agriculture Canada, K1A $0 C 7$

(C) Minister of Supply and Services Canada 1981

Cat. No. A53-1303/1981E ISBN: 0-662-11378-0

Printed 1967 Revised $1981 \quad 5 M-3: 81$

Aussi disponible en français

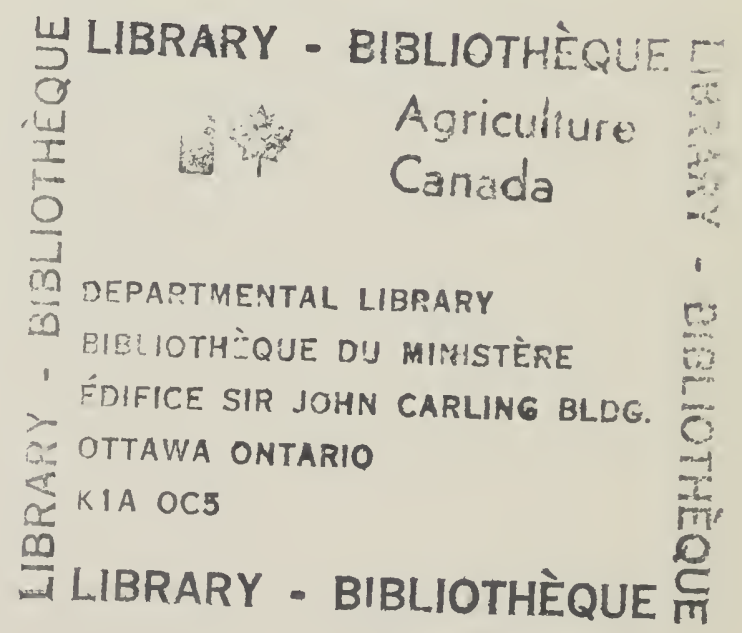

Cover Photograph Bellefontaine is a hybrid from a cross between Rhododendron fortunei and $R$. smirnowii. It was selected in 1974 at the Research Station, Kentville, N.S. 


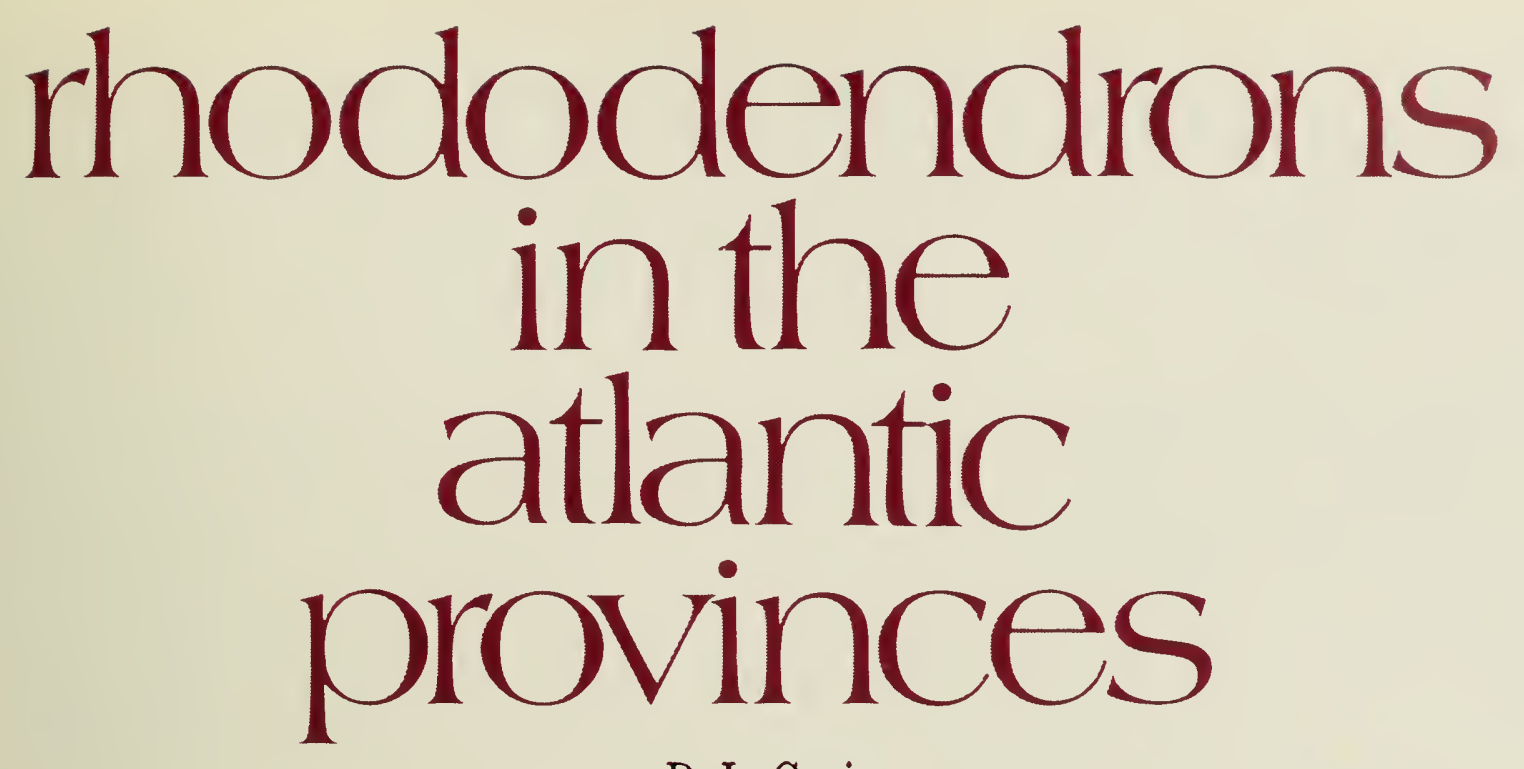

D. L. Craig

Research Station, Kentville, Nova Scotia

The genus Rhododendron, which includes the azaleas, contains nearly 1000 species that range in height from $2 \mathrm{in}$. $(5 \mathrm{~cm})$ to $80 \mathrm{ft}(24 \mathrm{~m})$. Of this number, only one, $R$. canadense Torr., is native to the Atlantic Provinces. This rosy purple azalea, which is commonly referred to as Rhodora, inhabits swamps, moist woods, pasture land, and roadsides. It is one of the most common and colorful spring flowering shrubs.

Most species of rhododendrons are native to tropical and subtropical climates. Only a few of them are native to North America and other temperate zones. Fortunately, several of these will grow well in the Atlantic Provinces.

In addition to the many species, plant breeders have developed thousands of hybrids. Those that have been named are called "cultivars," a term used to designate a hybrid that has originated under cultivation. Many of these cultivars can be grown in the Atlantic Provinces. Because cultivars are horticultural varieties, they are often referred to as varieties by gardeners.

The difference between species and cultivars is that the species are the native forms, which are found in the wild and reproduce themselves more or less true to form from seed. Cultivars are hybrids that have been developed by taking the pollen from one plant and using it to fertilize the pistil of a plant that is genetically different. Crosses can be made between two species, a species and a cultivar, or between two cultivars. The number of new hybrids that can be created is unlimited; however, none can be reproduced true from seed so they must be propagated by cuttings, grafting, or layering. Rhododendrons are very beautiful and long lived. The purpose of this publication is to supply the necessary facts about the many possibilities of these outstanding ornamental shrubs.

\section{Planting Site}

The natural setting for rhododendrons is open woodlands where the large trees provide protection from the wind and sun and the leaves from the trees supply a mulch. When planting rhododendrons, give them similar conditions if possible. 


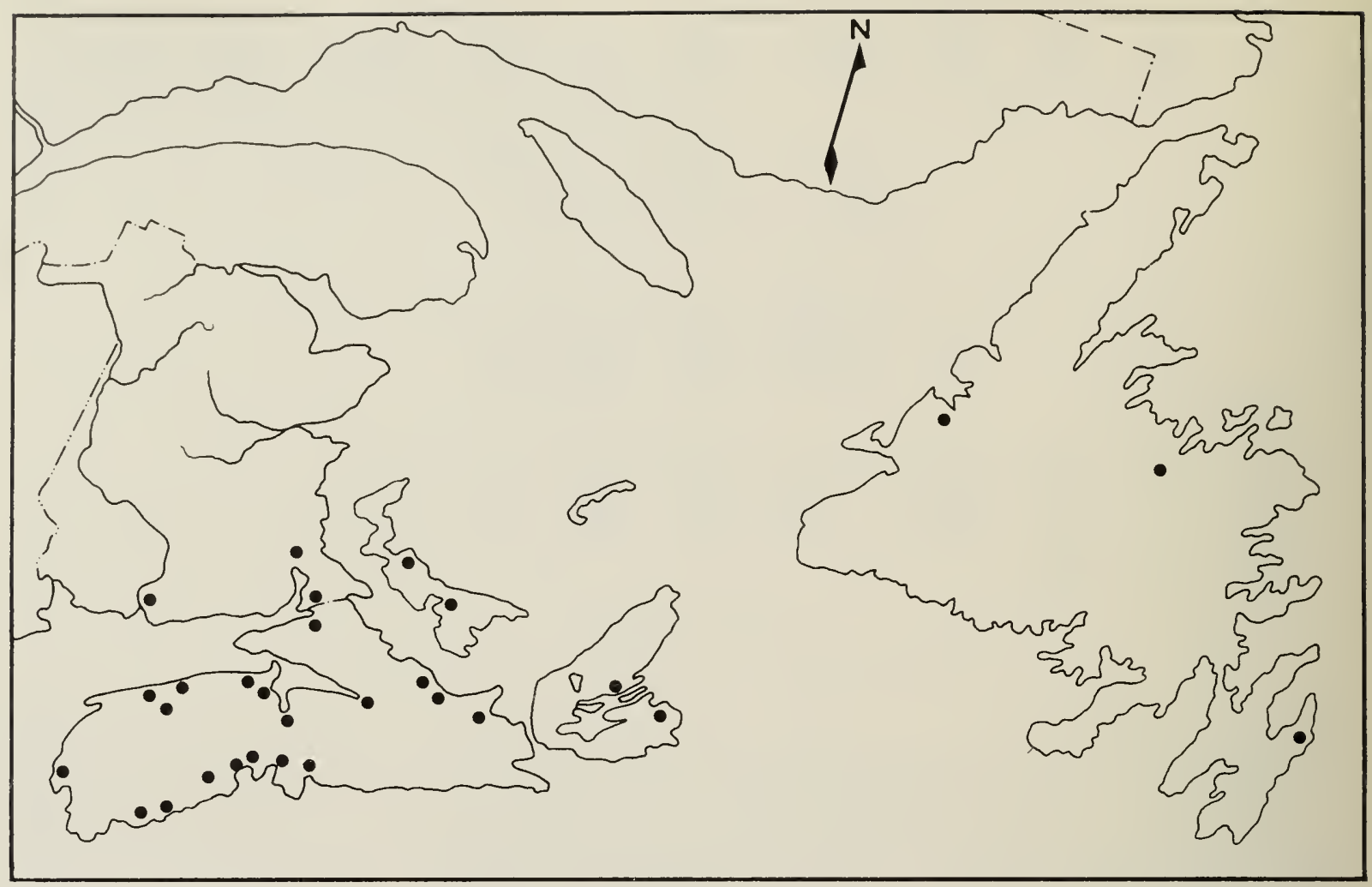

Figure 1. Distribution map showing areas where rhododendrons are cultivated successfully.

Pines and oaks are excellent companion trees because they are deep-rooted, and their leaves provide a suitable mulch. Elms, poplars, and ashes are shallow-rooted and so compete with rhododendrons for moisture and nutrients. Their leaves are not suitable for a mulch because they decay rapidly.

Excellent planting sites exist in many older residential areas where established trees provide high, moderate shade, and buildings and other plantings provide shelter from exposure to the prevailing wind. In many newer residential areas an effort has been made to retain most of the original tree and shrub cover. These areas also provide ideal planting sites for rhododendrons.

Avoid southern exposures unless protection can be given in the form of a permanent or a temporary windbreak or sunshade. The winter sun warms the foliage of exposed plants and may cause the sap to flow. If this occurs, the plant can be seriously damaged by a sudden drop in temperature.

\section{Uses in Landscape Planting}

For the past century the catawbiense hybrids have been the rhododendrons most commonly grown in the Atlantic Provinces. Although these plants may become large for a foundation situation, they provide an attractive background for shrub borders when planted behind smaller shrubs. These types become excellent specimen plants when they have enough space to develop properly. Suitable locations are on the edges of sparsely wooded areas and 
near the side of natural pools. The foliage of these rhododendrons is useful for home decoration. The bold green leaves are very effective in floral arrangements with many kinds of flowers, and they are probably at their best when used in low bowl arrangements for a table decoration. Quite a lot of foliage may be removed from older plants each year without apparent injury.

Smaller types such as $R$. catawbiense var. compactum Hort. or $R$. carolinianum Rehd., which have compact, rather formal shapes, can be used successfully in foundation plantings for globe-shaped accents. Lower-growing types, such as 'Ramapo', can be used instead of spreading junipers for contrast in form and texture. Most of the ordinary types are useful in shrub borders because they provide color during the flowering season and foliage effect throughout the year. Rhododendrons are particularly attractive when combined with all forms of yew.

Deciduous azaleas that are planted in groups give colorful garden displays during the flowering season and have brilliantly colored foliage in the fall. Many of these plants, which can grow in full sunshine, may be used successfully as specimens. Azaleas blend well with rhododendrons in mixed plantings.

Many new azalea cultivars have been introduced in recent years. Some of these belong to a spectacular group called the Knap Hills. This group includes the 'Exbury', 'Slocock', 'Ilam', and 'Knap Hill' hybrids. They are outstanding because of their floral color range, ruggedness, and hardiness. Many are pleasantly scented.

A number of the azalea species such as $R$. calendulaceum Torr., Flame Azalea; $R$. japonicum Suringar, Japanese Azalea; $R$. schlippenbachi Maxim., Royal Azalea; and $R$. vaseyi Gray, Pinkshell Azalea are also ideally suited to the Atlantic Provinces. Like the Knap Hills, their flower buds are hardy to at least $-29^{\circ} \mathrm{C}$.

The azalea species and the Knap Hills are hardier than most evergreen rhododendrons. They are of particular value in the colder regions and are less demanding in the amount of care required to produce good flowering plants.

\section{culture}

\section{Propagation by Seed}

Seed is used to propagate species because they produce seedlings that are more or less true to form. Seed may be sown in a heated greenhouse during the winter or in an unheated one or outdoors when the weather is warm. When seeding, place a sterilized, acid soil mix in the seed tray or pot, then cover with a half-inch layer of ground sphagnum moss. To prepare ground sphagnum rub the dried green moss through a wire-mesh screen. Moisten the moss and spread it over the soil. Seed directly on the moss and cover 

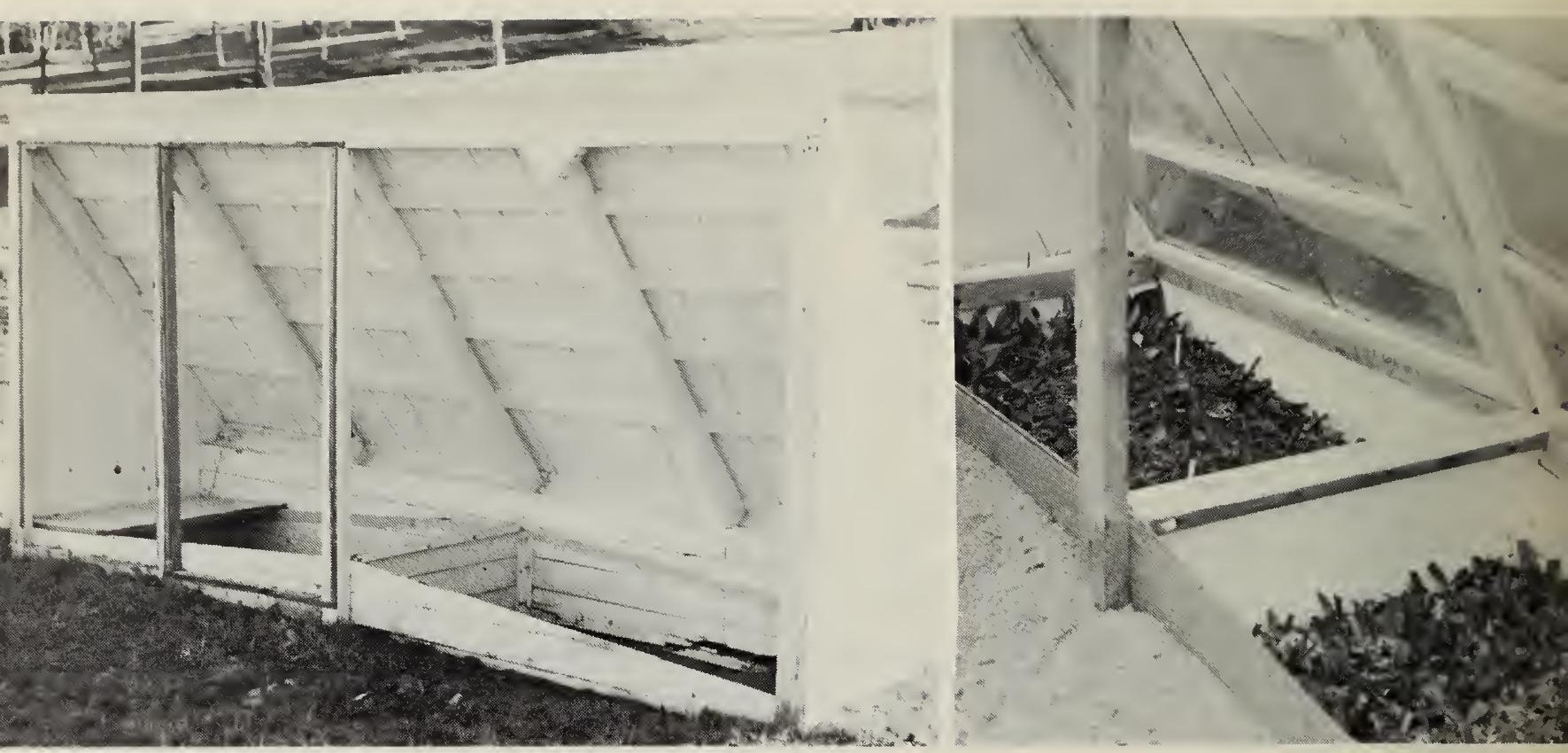

Figure 2. Solar frame with sun and wind shield (left) and with cuttings (right).

with a thin laver of ground sphagnum. Provide shade above the containers. Germination occurs within 3 weeks, if the temperature is maintained around $70^{\circ} \mathrm{F}\left(21^{\circ} \mathrm{C}\right)$. Transplant the seedlings into an acid soil mix after the first true leaves appear. When the seedlings are large enough, transplant them to an outdoor nursery.

\section{Propagation by Cuttings}

Nearly all rhododendron and azalea cultivars are propagated by cuttings that are rooted in a greenhouse or solar frame. The cuttings rooted in a solar frame often make the most satisfactory plants because their growth is controlled by the natural seasons and the plants do not depend on the artificial climate of a greenhouse.

Face a solar frame to the north (Fig. 2). In a greenhouse, use controlled mist and maintain a temperature of $70^{\circ} \mathrm{F}\left(21^{\circ} \mathrm{C}\right)$ by means of bottom heat from electric cables (Fig. 3). Sharp sand and peat moss in equal parts make a satisfactory rooting medium.

Take evergreen rhododendron cuttings in late summer or early fall before the new growth becomes very woody. With azaleas take the cuttings quite early in the growing season as soon as the new shoots are stiff enough to be handled without wilting. Make all cuttings 4 to $5 \mathrm{in}$. (10 to $12.5 \mathrm{~cm}$ ) long from healthy, medium vigorous shoots of the current season's growth. Leave four to six leaves at the top and with rhododendrons only reduce their length by one-third to one-half. Wound the cuttings of rhododendrons by slicing about an inch $(2.5 \mathrm{~cm})$ of the bark from one side of the base to stimulate root formation (Fig. 3). Dip cuttings of cultivars that are difficult to root in hormone powder or liquid formulations prior to insertion into the rooting medium. Make certain that the cuttings in a solar frame do not dry out from lack of moisture. 

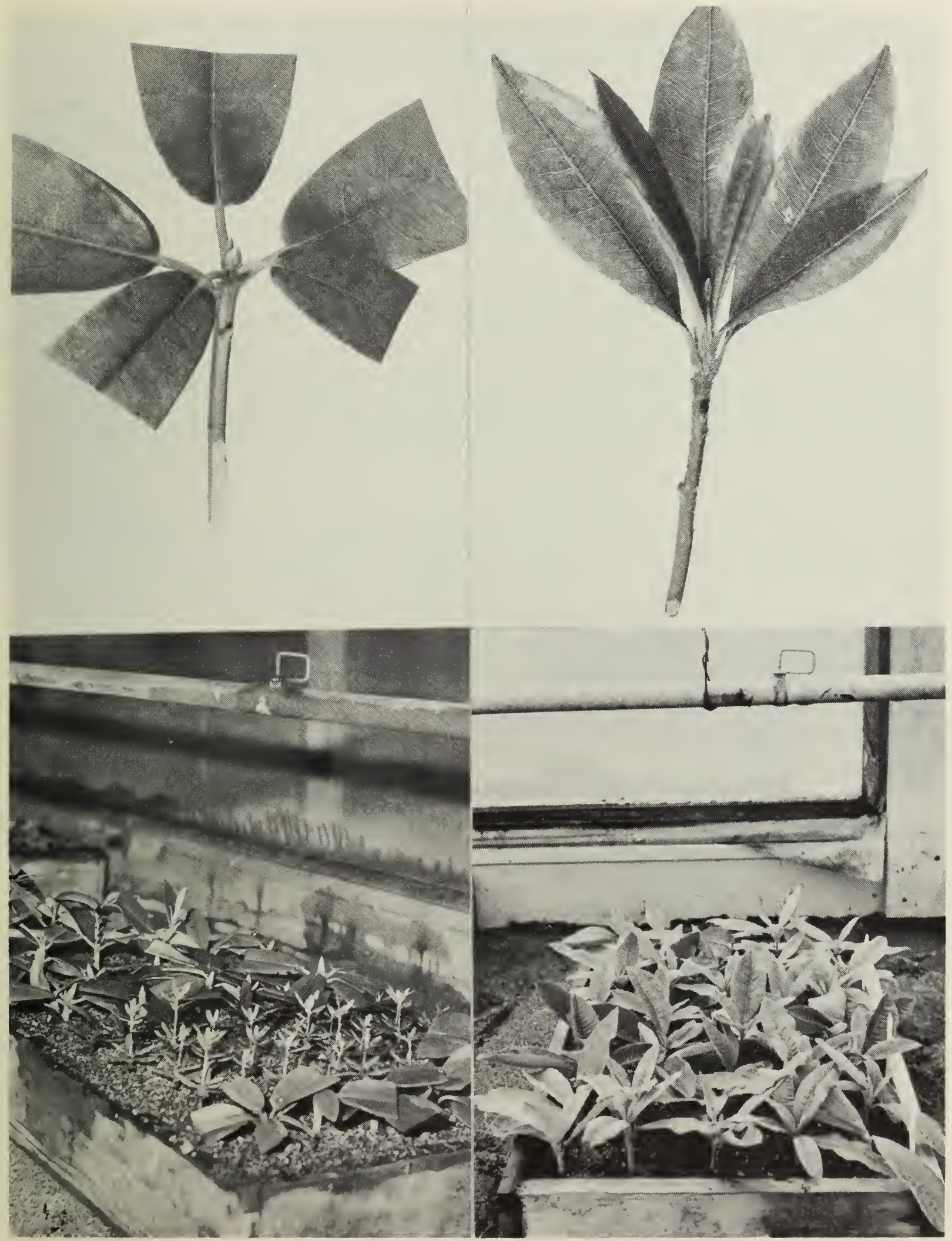

Figure 3. Rhododendron cutting (upper left), azalea cutting (upper right); rhododendron cuttings propagated with the assistance of mist, bottom heat, and artificial light (lower left), azalea cuttings in propagation bench (lower right). 


\section{Propagation by Layering}

Rhododendrons may be propagated by layering, but it is a slow method. It can be used to propagate an old plant with some low branches that can be bent down in a shallow trench. When layering, notch the underside of the branch and peg it down. Cover with 3 or 4 in. ( 8 or $10 \mathrm{~cm}$ ) of soil. Keep moist and leave in position for several months until roots form at or near the notch. Then sever the branch from the old plant, dig it up and put it into a nursery row for a couple of years to develop side branches.

\section{Propagation by Grafting}

New techniques have made it possible to propagate most rhododendrons from cuttings so very little grafting is done except for special purposes. Seedlings of $R$. ponticum L. are commonly used as understock, but any easily rooted cultivar or species seedling that is fairly closely related to the scion material may be used. The cleft or saddle graft is commonly used.

\section{Soil for Planting}

Good soil is needed. Deep, sandy loam soils that are well supplied with humus are ideal. They drain well and this is important because rhododendron roots will not grow well in wet soil. Also these soils hold enough moisture to encourage good growth. The soil should be acid ( $\mathrm{pH} 4.5$ to 5.5) in reaction. Your provincial department of agriculture will test a sample of your soil and tell you the amount and kind of chemical to use.

\section{Selecting Plants}

All sizes of rhododendrons are easy to transplant, so the choice of large or small plants is probably determined by the cost of the plants and the importance of the immediate landscape effect. Smaller plants rarely have flower buds whereas larger plants are generally well budded and will flower the first season.

Regardless of the size of plant you need, choose only sturdy, low-branched plants that have a good framework of main branches. Foliage color varies with types, but good plants have leaves that are healthy in appearance and free from insect, disease, or mechanical injury. Ideally, the roots are contained in a good ball of moist earth, solidly attached to the plant.

\section{Setting the Plants}

Spring planting is recommended for the Atlantic Provinces. Early spring planting favors the formation of new roots before the warm weather begins. Fall plantings may not have had time to form new root growth before cold drying winds cause damage.

If you are planting in naturally well-drained soil, individual holes may be used or beds may be prepared. Dig individual holes 15 to $18 \mathrm{in}$. (38 to $46 \mathrm{~cm}$ ) deep with straight sides. The diameter of the hole should be at least 12 in. $(30 \mathrm{~cm})$ greater than the diameter of the soil ball of the plant to be placed in the hole. Plant a rhododendron at exactly the same depth 
as when it was growing in the nursery. Place prepared soil below and around the soil ball and firm it by hand to avoid damaging the fine roots (Fig. 4).

To obtain a satisfactory soil mixture for all rhododendrons use: 1 part topsoil, 1 part clean sharp sand, and 2 parts peat. Add 1/2 oz (14 g) of ferrous sulfate (Copperas) and $5 \mathrm{oz}(142 \mathrm{~g})$ of magnesium ammonium phosphate per bushel (36 litres) of mix. Four ounces (113 g) of superphosphate and 1/2 oz (14 g) of magnesium sulfate (Epsom salts) may be used in lieu of magnesium ammonium phosphate. Moisten but do not wet the soil, peat, and sand before thoroughly mixing all the ingredients. If you make smaller or larger amounts of this mixture, keep the proportions of the ingredients the same.

To prepare beds in locations where the soil is heavy but well drained, spread $6 \mathrm{in}$. $(15 \mathrm{~cm})$ of peat over the bed area, measuring the quantity of peat in bushels (litres). Use the formula above and add the necessary ingredients. Add sand in proportion to the amount of peat used and rototill or work the ground $12 \mathrm{in.}(30 \mathrm{~cm})$ deep. If the soil is sandy do not add sand.

If the planting area is poorly drained or the soil is alkaline, build a raised bed on the surface of the soil. Outline the bed with rock or logs 12 to 18 in. (30 to $45 \mathrm{~cm}$ ) high and fill the enclosure with prepared soil.

Thoroughly water the soil around each plant immediately after planting. Where bed planting is used, water all the soil in the beds. As soon as the watering is completed apply a mulch.

Figure 4. Correct planting.

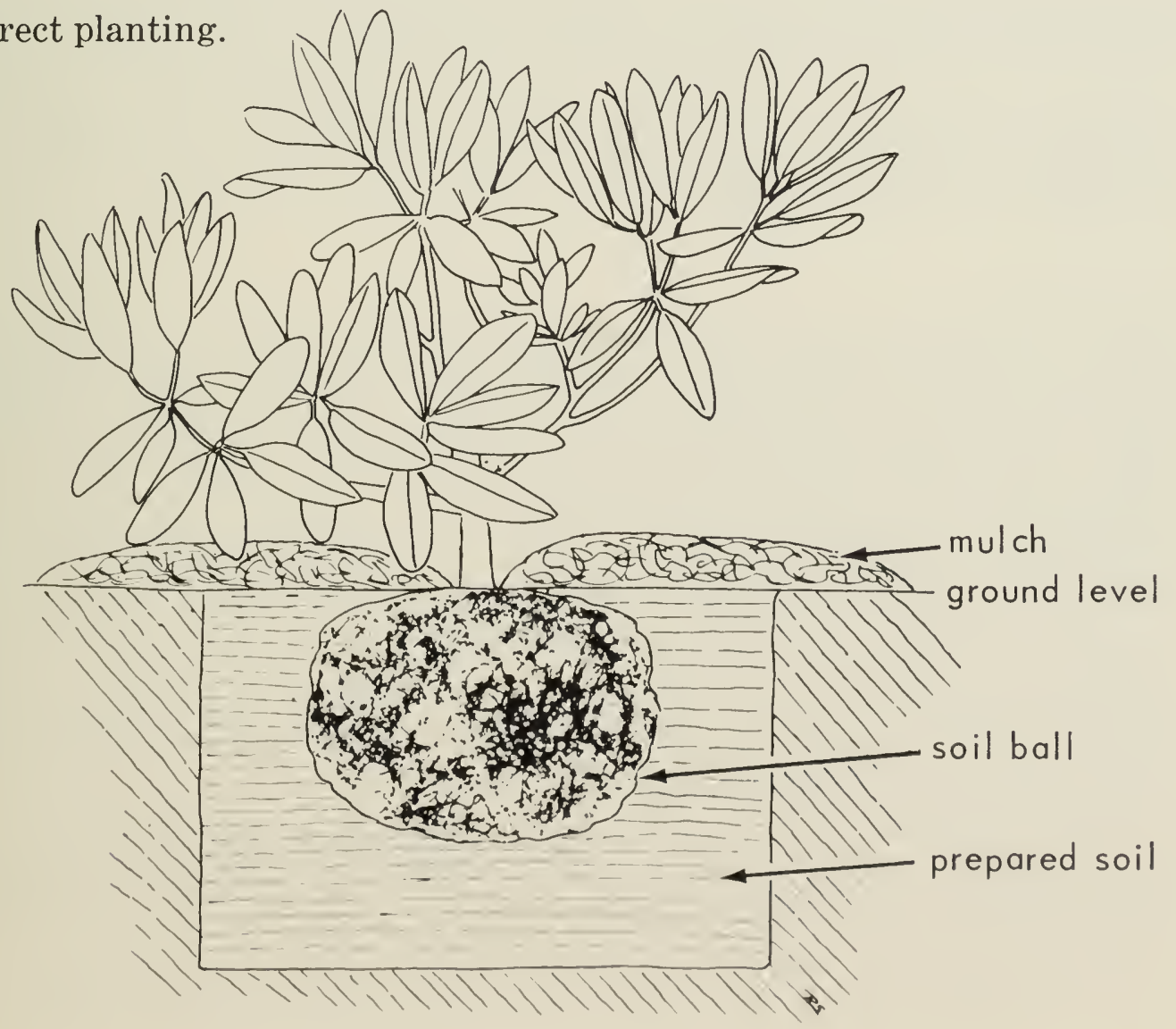




\section{Mulching}

The rhododendron has a fine, shallow root system, which is sensitive to changes in air temperature at ground level and to changes in soil moisture. In its native habitat, the rhododendron root system is protected from rapid freezing and drying by a mulch, usually of leaves and forest litter. Therefore, it is necessary to protect planted rhododendrons with a mulch.

A suitable mulch is porous, can absorb and retain moisture, and will not dry out to the point where it actually sheds water and prevents it from reaching the roots. It is heavy enough or has its component parts interlocking so that it will not blow away. In addition, a mulch should be attractive in appearance, especially in foundation or ornamental bed plantings.

Many amateur gardeners mistakenly think that peat is a good mulch for rhododendrons. If used to improve the soil, peat is excellent, but as a mulch it may be harmful. Rhododendron roots will readily penetrate a peat mulch, but during extended dry periods peat will dry to the point where it becomes powdery and sheds water, and in this dry state it often blows away. The fine roots are then exposed to the air and root damage that sometimes is fatal may follow.

Spread the mulch out from the main stem of the plant to at least as far as the spread of the plant itself. Keep the mulch at the proper level by adding to it every year until the branches and leaves of the plant reach the ground and the plant holds its own fallen leaves as a mulch.

Oak leaves 6 to $8 \mathrm{in}$. ( 15 to $20 \mathrm{~cm}$ ) deep, pine needles 2 to $3 \mathrm{in}$. (5 to $8 \mathrm{~cm}$ ) deep, and wood chips, chopped bark, sawdust, or buckwheat hulls 1 to 3 in. (3 to $8 \mathrm{~cm}$ ) deep are suitable mulches. Ground covers such as Japanese spurge (Pachysandra terminalis Sieb. \& Zucc.) are sometimes used in place of a mulch for rhododendrons.

\section{Fertilizing}

The nutrient requirements of rhododendrons are low and most soils are able to supply the elements needed for healthy growth. In areas where the soil is poor and the plants are unhealthy and are not growing well, feed them small quantities of prepared rhododendron fertilizers. In most soils nitrogen is the element most likely to be needed. A nitrogen deficiency is indicated by leaves that are yellowish or pale green but otherwise normal. To correct this condition, spread ammonium sulfate or urea around the plant in the area covered by the branches. Use ammonium sulfate at the rate of $1 \mathrm{oz}(28 \mathrm{~g})$ and urea at $1 / 2 \mathrm{oz}(14 \mathrm{~g})$ per bush per year until the bush matures. Give a mature bush not more than $1 / 2 \mathrm{lb}(227 \mathrm{~g})$ of ammonium sulfate or $1 / 4, \mathrm{lb}(113 \mathrm{~g})$ of urea.

Do not fertilize newly set plants. Apply fertilizer early in the growing season. Avoid late summer and fall applications because they may stimulate late growth that is susceptible to winter injury. 


\section{Watering}

In most places in the Atlantic Provinces established rhododendrons that are well mulched do not need extra water. But on light, sandy soils during prolonged hot, dry spells, they will need a good soaking at weekly intervals. Plants that have not yet become well established will also need additional water during dry weather.

A regular supply of moisture is very necessary especially for newly set plants. The objective is to keep the plant from wilting without making it excessively wet. Most of the rhododendrons' roots are near the surface and if they have moisture the plant will thrive.

\section{Weeding and Cultivating}

Mulch around rhododendron plants usually discourages weeds, but if they do grow, pull them out. Do not cultivate around the plants, as this will destroy many of the fine roots and perhaps cause serious injury. After you apply the mulch, do not disturb the soil surface.

\section{Winter Protection}

Winter protection is usually needed until the plants become well established in their new location, which takes 1 to 3 years after planting. A simple, effective method is to point three or four spruce or other evergreen branches or small trees and force the points into the ground at an angle around each plant. Tie the tips together to form a tepeelike tent over the plant. Cover the plants just before freeze-up and remove the tents after all frost is out of the ground in the spring. Burlap or other woven material may also be used to protect individual plants.

Snowfencing serves as a windbreak when placed around beds of rhododendrons. Polyethylene plastic sheeting can be attached to the fence to improve its effectiveness.

\section{Pruning and Shaping}

To prune and shape rhododendron plants properly, you must know their growth habits. There are one or two flushes of growth each year. The first flush usually ends with a whorl of leaves and a group of vegetative buds, which generally consists of one large terminal and several small axillary buds (Fig. 5). The second flush usually terminates in the same way, except that there is a flower bud rather than a vegetative one at the tip of a shoot. Flower buds are much larger and thicker than vegetative buds.

If there is a vegetative terminal when growth starts, a single shoot develops from this bud and the axillary buds remain dormant. This type of growth, when continued for more than one growing season, results in a leggy plant. However, if you remove the vegetative terminal in the fall, from two to five axillary buds will develop shoots and a well-branched compact plant will form. When flower buds are present as terminals, several axillary buds develop shoots during the next flush of growth. Thus the presence of terminal flower buds assures self-pruning and shaping of the plant. If some 

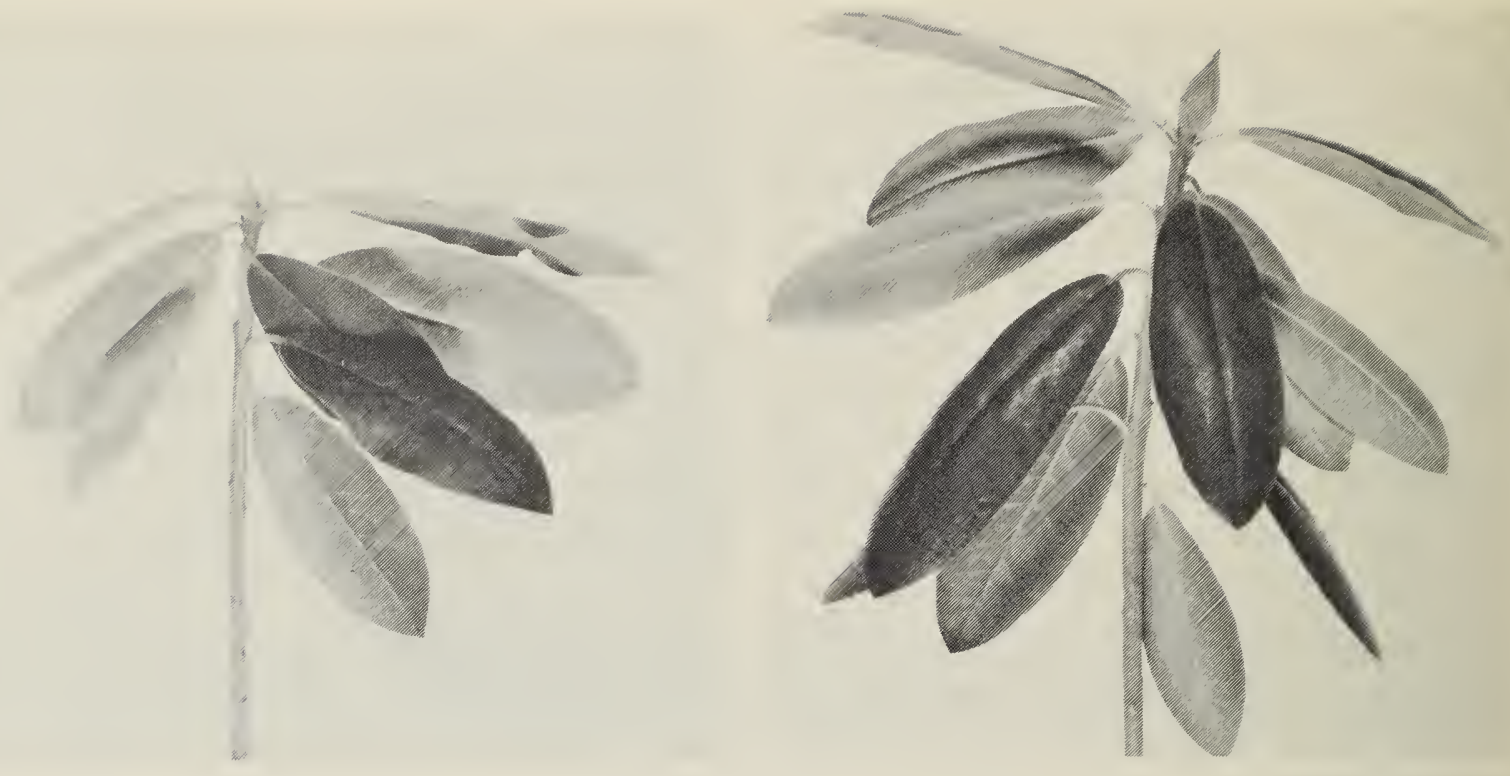

Figure 5. Vegetative bud at shoot terminal (left); flower bud at shoot terminal (right).

of the branches have terminal flower buds and others have terminal vegetative buds, remove the vegetative terminals in the fall to keep the plant in balance. When terminal vegetative buds are not removed, one or more branches of a plant may grow out well beyond the other branches. To correct this, simply cut the offending branch back to the whorl of leaves that will keep it in balance with the rest of the plant (Fig. 6). New shoots will develop from the axillary buds during the next flush of growth.

To rejuvenate a leggy plant, in early spring locate a whorl of leaf scars on the bark and cut back to just above this point. New shoots will arise from the dormant axillary buds in this section. When making a cut on a branch, cut as close as possible to a whorl of shoots or leaves or to a stem so that no stub is left (Fig. 7).

Old plants that have grown too large can be pruned back and rejuvenated. In the spring, remove about one-third of the taller branches the first year, half of the remaining branches the next, and the balance the third year. Cut back to within 2 or $3 \mathrm{ft}(61$ or $91 \mathrm{~cm})$ of the ground or whenever smaller side branches are available for starting a new framework. Some rhododendrons can be cut back to ground level. Adventitious buds in the stump area will produce new shoots. This is a drastic treatment and not always successful.

\section{Shade}

Shade affects soil and air temperatures so it is an important factor in rhododendron growth. Partial shade is desirable even though some rhododendrons grow well in full sun. Partial shade prolongs the period of flowering and prevents fading of flower color. Full shade is undesirable because plants grow tall and leggy, the lower branches tend to die off, and flower bud formation is much less than in partial shade or full sun. 


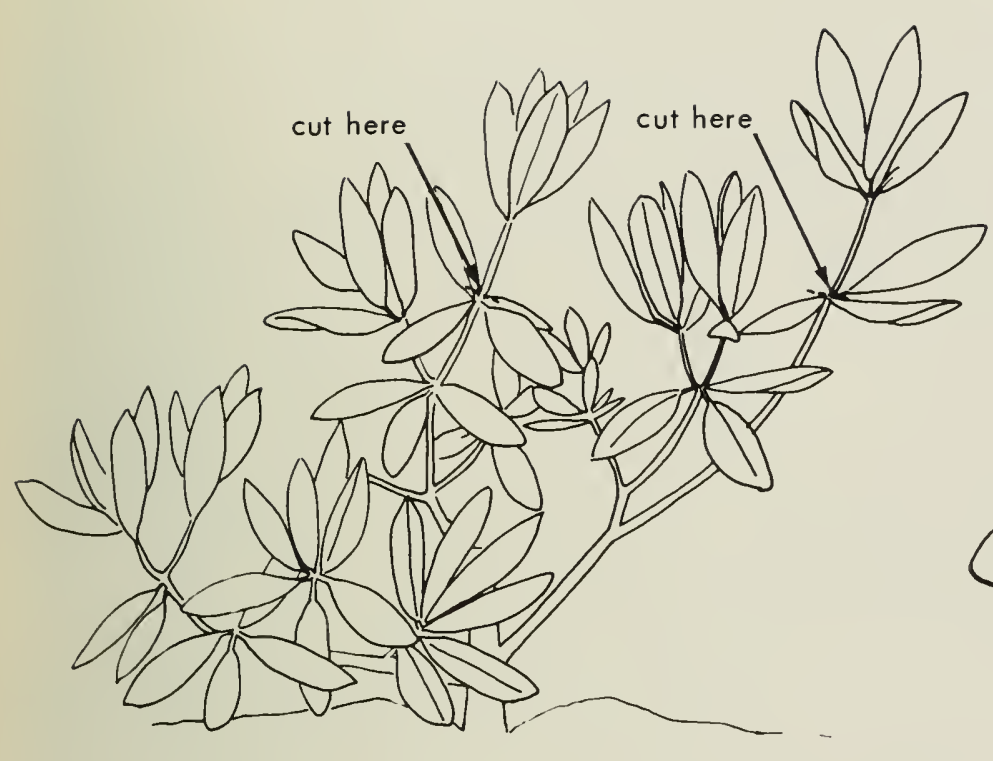

Figure 6. Shape a plant that is out of balance.

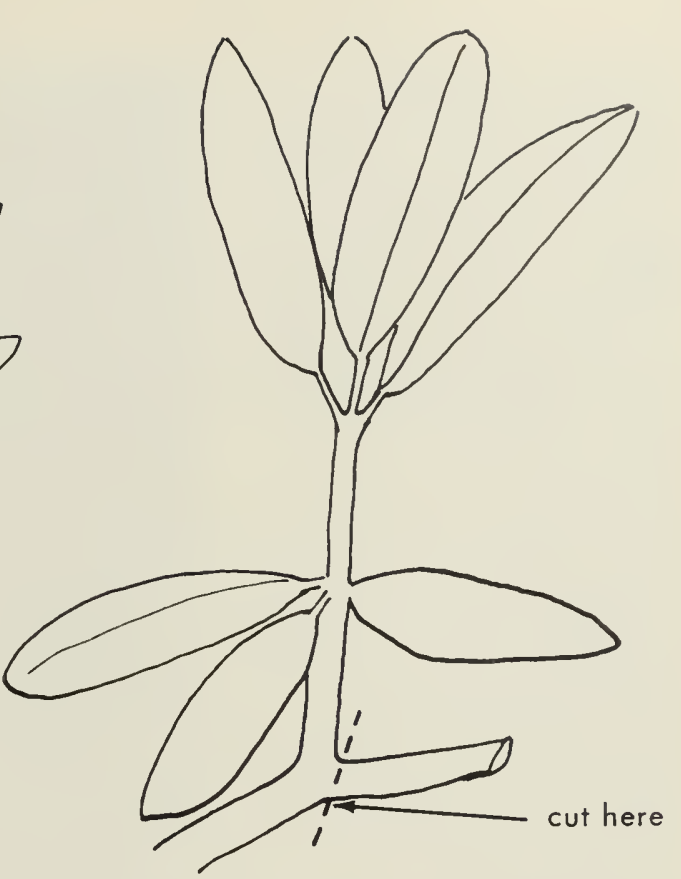

Figure 7. Cut off pruning stubs.

\section{Removal of Old Blooms}

With the large flowering types of rhododendrons remove the flowers as soon as they wither. Break off the flower cluster with a quick snap of the thumb pushing on the base of the cluster stem. Avoid damaging the axillary buds (Fig. 8). The removal of old flower clusters improves the appearance of the plant, prevents mold developing on the old flowers and then growing into the stems, and avoids a set of seed. Plants that have a heavy seed set may be weakened if the flowers are not removed. The small-flowered rhododendrons do not generally need this treatment.

Figure 8. Faded flower cluster (left). Arrows show small dormant axillary buds that may be injured if care is not taken when clusters are removed (right).
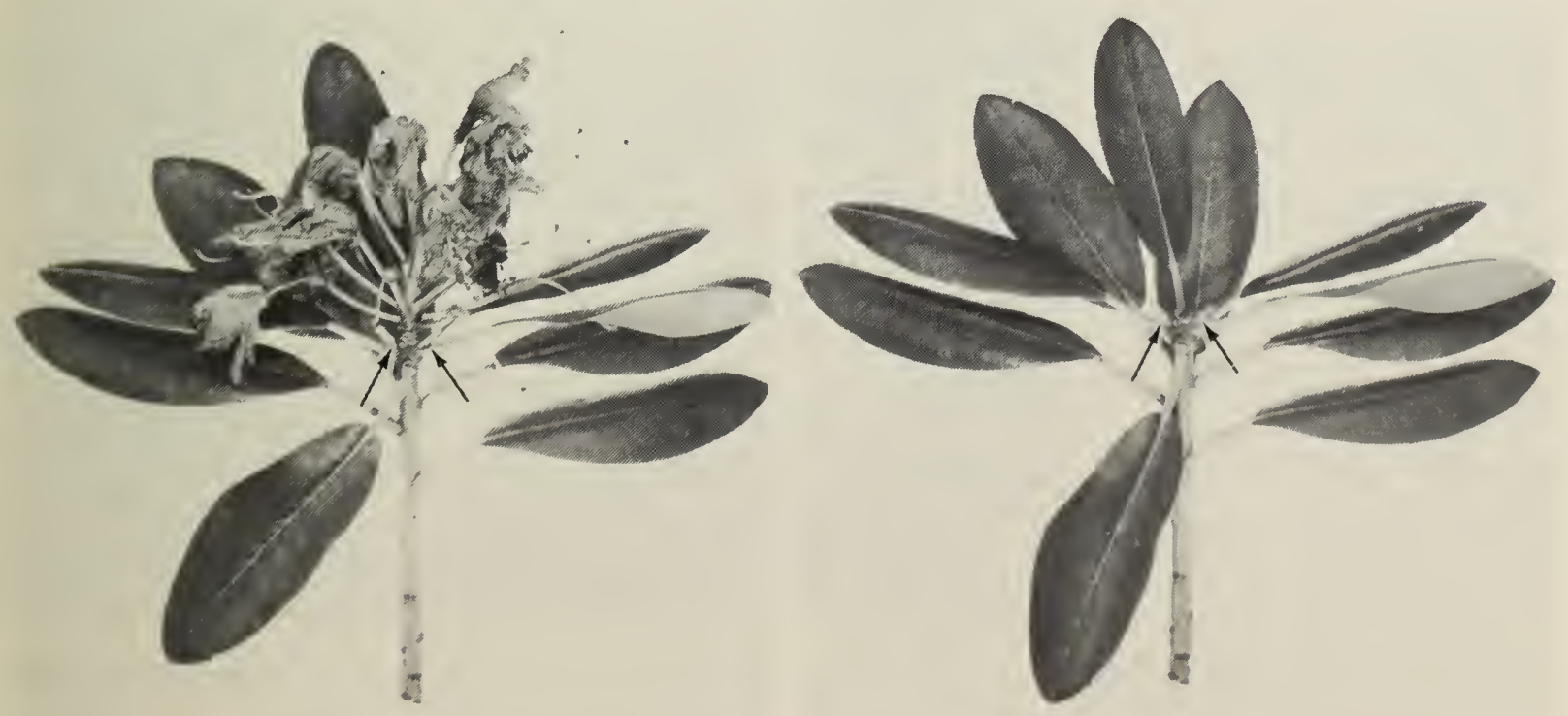


\section{Winter Iniury}

Severe cold, especially where the plants are in an exposed position, or cold winds may cause a form of injury that may not become apparent until growth starts in the spring. Sometimes this injury is the result of the March winds. The leaves turn yellow, then brown, as if burned, and young twigs and sometimes the whole plant may be killed. The means of control is to discourage late growth, give the tops some protection when necessary, and protect the roots with a good mulch.

\section{Yellowing of the Leaves}

Chlorosis, or a yellowing of the leaves while the veins remain green, may result from a number of different causes. The most common cause is too much lime in the soil. This can be detected by determining the $\mathrm{pH}$ and, if necessary, steps should be taken to adjust the reaction. If the soil is thin and deficient in organic matter, lack of moisture and consequent restriction of root growth, and injury to roots may result and bring about chlorosis. If the soil is very poor, chlorosis may result from a lack of nutrients, and fertilizer is needed. All of these cases will be aggravated by extreme lack of moisture.

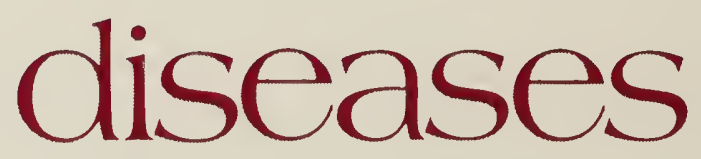

Rhododendrons are usually free from diseases, but occasionally plants may be severely attacked by fungal pathogens. Generally diseases are more common on the leaves than on the wood. One of the main avenues of fungal infection is through injuries to the foliage or wood. Cultivars vary in their susceptibility to physiological injury such as that caused by wind and low temperatures. Species and cultivars that suffer physiological damage may become infected with parasitic fungi, which usually aggravate the injury. In a favorable environment, the more aggressive fungal pathogens may penetrate host tissue without the aid of an injury to cause an infection.

In 1972, a survey for pathogenic fungi after a severe foliage blight of rhododendron plants at the Station, showed that most of the fungi reported on this host in North America are present here. Over 20 species of fungi from very aggressive to weak pathogens were found on leaves and wood. The fungus Glomerella cingulata (Stonem.) Spauld. \& Schrenk., the state, conidial Gloeosporium rhododendri Bri. \& Cav., occurred more often than other fungi as the primary cause of infections on leaves and wood. Botryosphaeria rhodorae (Cooke) Barr, the state, conidial Phyllostictina maxima (Ell. \& Ev.) Petrak and spermatial Asteromella saccardoi (Thum.) Petrak, was the second most important cause of primary infections (Fig. 9). The three forms of this fungus represent three different states in the life history of the organism and they can occur independently of each other. Diplodina eurhododendri Voss was the third most important primary pathogen as the cause of a leaf spot (Fig. 10). Most of the other fungi are weak, but positive parasites and infections may advance from an initial colonization of weak or injured areas on leaves or wood. 

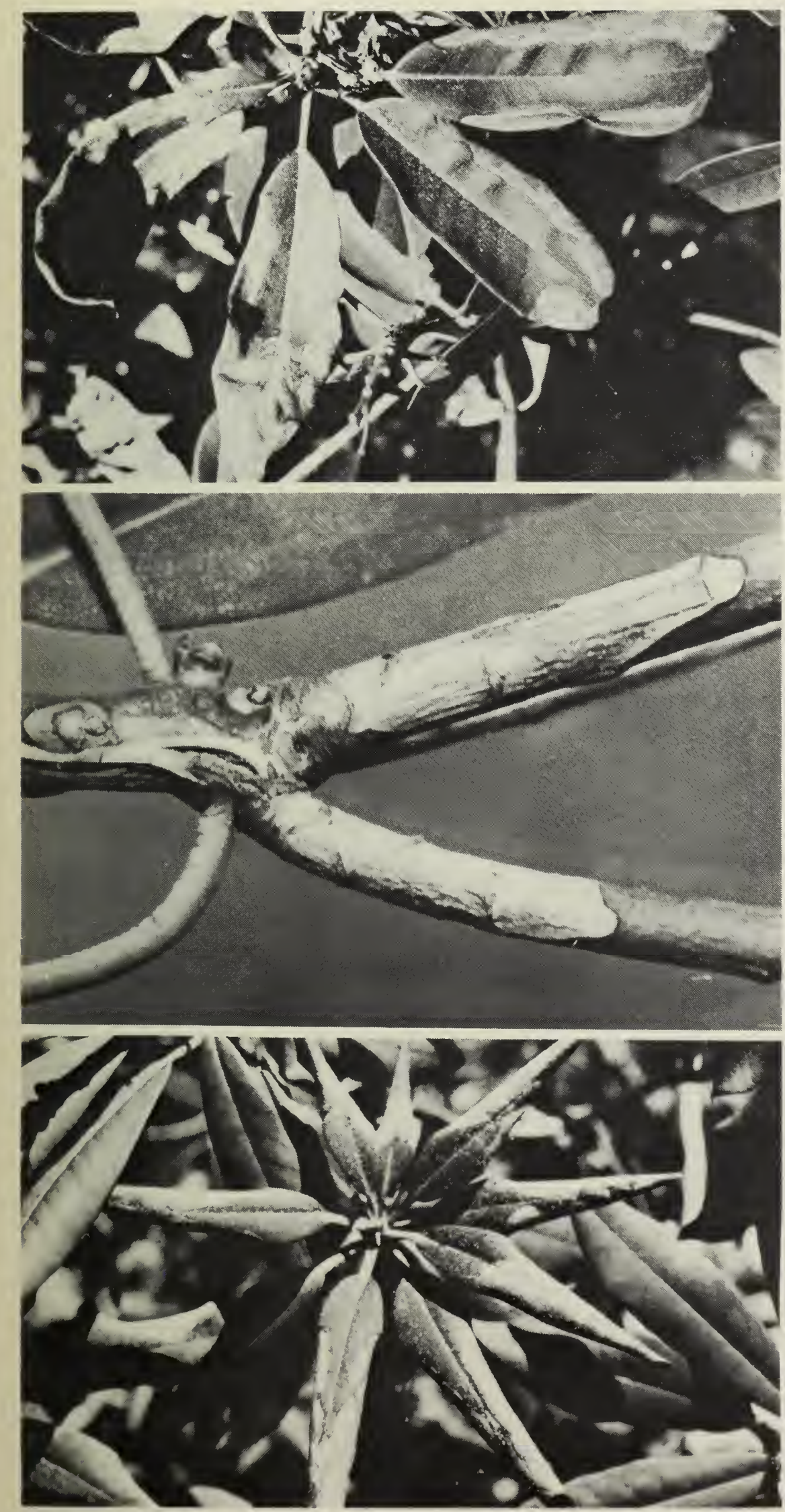

Figure 9. Glomerella cingulata on foliage (upper) and on wood (center) of rhododendron. Botryosphaeria rhodorae on foliage of rhododendron (lower). 
Figure 10. Diplodina eurhododendri on rhododendron (upper and center) ; Microsphaera penicillata (mildew) on azalea (lower).

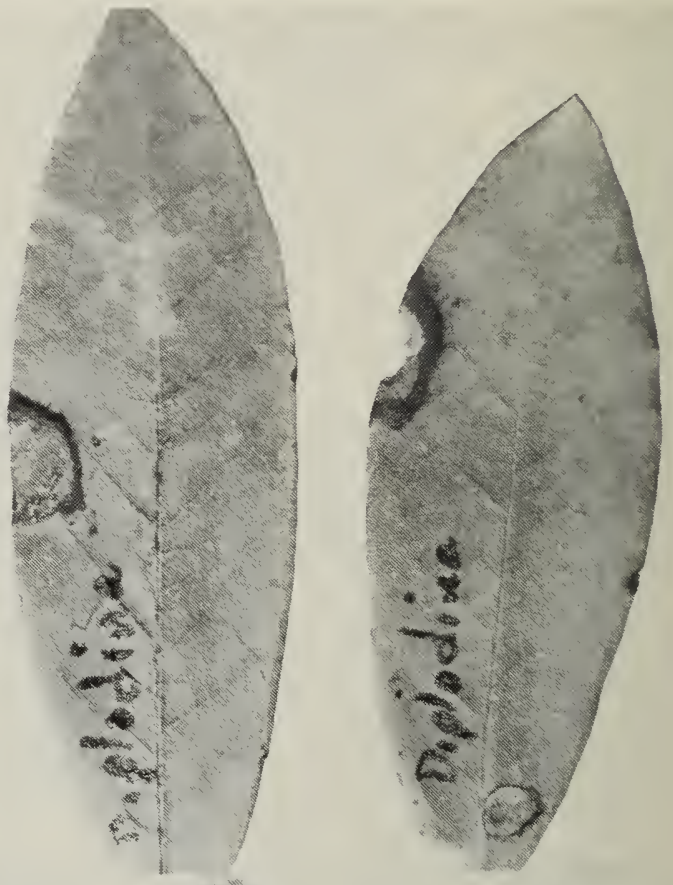


Botrytis cinerea Pers. the cause of gray mold or Botrytis blight may become a problem in the cutting bed under conditions of high humidity, which favor the pathogen. Gray mold is seldom a problem in the garden with adequate ventilation, but it can attack flower's and flower buds after winter injury. This disease is difficult to control by measures other than strict sanitation and by avoiding practices that favor high humidities.

It is not surprising that most, if not all, leaf-spot fungi reported on rhododendrons occur in Eastern Canada. Undoubtedly, many fungi were imported with plants from domestic and foreign nurseries. Others may be present on native ericaceous plants related to rhododendrons or even on other hosts from plant families taxonomically unrelated to rhododendrons.

Preventing infection or controlling diseases is largely a matter of avoiding winter injury through which the pathogen may gain a foothold in the host. The selection of a good growing site, along with the use of recommended cultivars and good cultural practices promote healthy plant growth so that fungal pathogens cause little trouble. At times it may not be possible to prevent frost damage, especially on cultivar's near the limits of their hardiness. When this occur's, it is best to remove and burn all dead and diseased parts rather than applying a fungicide spray or dust. Chemical control may only be justified in large plantings where pruning would be impractical. Leaf-spot fungi and the mildew fungus, Microsphaerc penicillata (Wallr. ex Fr.) Lév. which also attacks the foliage, can be controlled with regular applications of fungicidal sprays or dusts.

However, with proper culture, healthy plants will be able to resist physiological damage and disease much better than less thrifty ones.

Figure 11. Adult whiteflies (left); underside of infested leaf with tarnished appearance and scalelike structures from which adult whiteflies emerged (right).

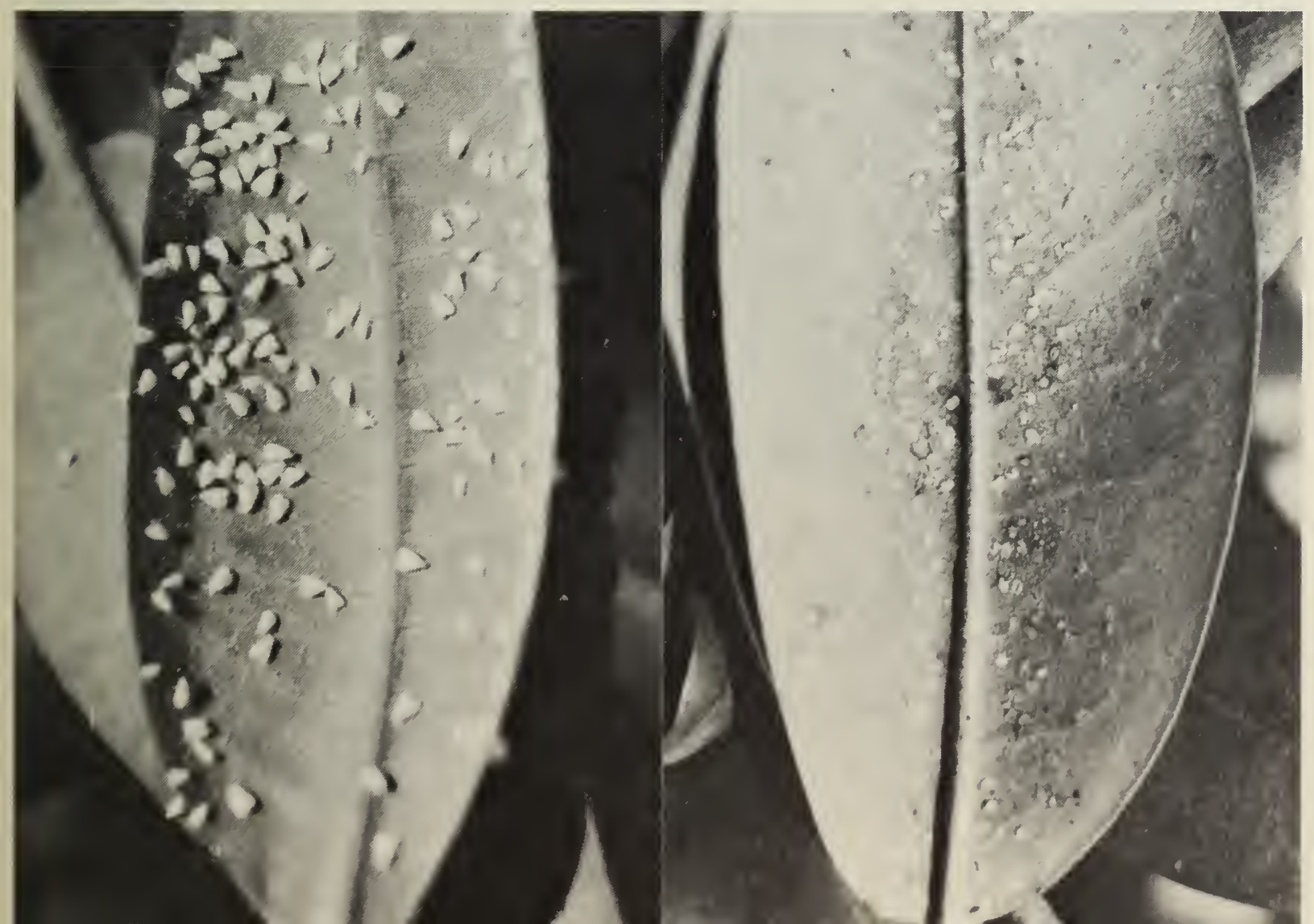


Evergreen rhododendron species

*R. carolinianum

$* R$. catawbiense var. compactum

R. catawbiense var. album

R. maximum

*R. russatum
H-1 pink

H-1 magenta

H-1 white

$\mathrm{H}-1$

$\mathrm{H}-2$
Quality $^{2}$
4/4 June 4

$3 / 4 \quad$ June 17

$3 / 4 \quad$ June 16

$2 / 2 \quad$ July 10

4/4 May 27

\section{Deciduous rhododendron} species
*R. mucronulatum
$\mathrm{H}-1$ pink mauve
$3 / 3$
May 14

\section{Evergreen rhododendron cultivars}

$\begin{array}{lllll}\text { Acadia } & \text { H-2 } & \text { pink } & 4 / 3 & \text { June 16 } \\ \text { Album Elegans } & \text { H-1 } & \text { white } & 4 / 3 & \text { June 21 } \\ \text { America } & \text { H-1 } & \text { red } & 3 / 2 & \text { June 16 } \\ \text { Bellefontaine } & \text { H-1 } & \text { pink } & 4 / 4 & \text { June } 7 \\ \text { *Blue Peter } & \text { H-2 } & \text { blue } & 4 / 3 & \text { June 11 } \\ \text { *Boule de Neige } & \text { H-1 } & \text { white } & 4 / 4 & \text { June 7 } \\ \text { *Catawbiense Album } & \text { H-1 } & \text { white } & 4 / 2 & \text { June 18 } \\ \text { *Catawbiense Boursault } & \text { H-1 } & \text { rose lilac } & 4 / 4 & \text { June 14 } \\ \text { Catawbiense Grandiflorum } & \text { H-2 } & \text { lilac } & 3 / 3 & \text { June 20 } \\ \text { Caroline } & \text { H-2 } & \text { lavender } & 3 / 3 & \text { June 13 } \\ \text { Conewago } & \text { H-1 } & \text { pink } & 3 / 3 & \text { May 26 } \\ \text { County of York } & \text { H-2 } & \text { white } & 4 / 4 & \text { June 9 } \\ \text { Evangeline } & \text { H-1 } & \text { pink } & 4 / 3 & \text { June 14 } \\ \text { *Everestianum } & \text { H-2 } & \text { rose lilac } & 4 / 3 & \text { June 18 } \\ \text { *Holden } & \text { H-2 } & \text { rose red } & 4 / 3 & \text { June 9 } \\ \text { Ice Cube } & \text { H-1 } & \text { white } & 4 / 4 & \text { June 17 } \\ \text { Lee's Dark Purple } & \text { H-2 } & \text { purple } & 3 / 3 & \text { June 19 } \\ \text { Mist Maiden } & \text { H-2 } & \text { white } & 4 / 5 & \text { June 6 } \\ \text { *Nova Zembla } & \text { H-1 } & \text { red } & 3 / 3 & \text { June 14 } \\ \text { Pioneer } & \text { H-1 } & \text { pink } & 3 / 2 & \text { May 19 } \\ \text { *P.J.M. } & \text { H-1 } & \text { lavender pink } & 4 / 3 & \text { May 21 } \\ \text { *Ramapo } & \text { H-1 } & \text { violet } & 4 / 4 & \text { May 29 } \\ \text { Roslyn } & \text { H-1 } & \text { pink } & 4 / 4 & \text { June 10 } \\ \text { Roseum Elegans } & \text { H-1 } & \text { lavender pink } & 3 / 3 & \text { June 16 } \\ \text { Scintillation } & \text { H-3 } & \text { pink } & 4 / 3 & \text { June 11 } \\ \text { Spring Parade } & \text { H-1 } & \text { red } & 4 / 4 & \text { June 7 } \\ \text { Windbeam } & \text { H-1 } & \text { pink } & 3 / 4 & \text { June 4 }\end{array}$

${ }^{1}$ Hardiness rating method is that used by the American Rhododendron Society. H-1, hardy to $-32^{\circ} \mathrm{C} ; \mathrm{H}-2$, hardy to $-26^{\circ} \mathrm{C} ; \mathrm{H}-3$, hardy to $-21^{\circ} \mathrm{C}$.

${ }^{2}$ Quality rating method is that used by the American Rhododendron Society. $1=$ poor, $2=$ below average, 3 = average, $4=$ above average, $5=$ superior. A variety rated $4 / 2$ indicates above average bloom quality and below average plant type.

${ }^{3}$ Average date of full bloom at Kentville is a 5-year average. 
Flower

Average date ${ }^{3}$

Hardiness ${ }^{1}$ color

of full bloom

Deciduous azalea species

$\begin{array}{lllll}R \text {. atlanticum } & \text { H-2 } & \text { white pink } & 3 / 3 & \text { June } 15 \\ R \text {. bakeri } & \text { H-2 } & \text { orange red } & 4 / 3 & \text { July } 6 \\ * R \text {. calendulaceum } & \text { H-1 } & \text { orange scarlet } & 4 / 4 & \text { June 22 } \\ * R \text {. japonicum } & \text { H-1 } & \text { yellow red } & 3 / 2 & \text { June 10 } \\ R \text {. luteum } & \text { H-1 } & \text { yellow } & 3 / 3 & \text { June } 8 \\ R \text {. roseum } & \text { H-1 } & \text { pink } & 3 / 4 & \text { June } 9 \\ * R \text {. schlippenbachi } & \text { H-2 } & \text { pink } & 4 / 4 & \text { May 29 } \\ * R \text {. vaseyi } & \text { H-1 } & \text { white pink } & 4 / 4 & \text { June 2 }\end{array}$

Deciduous (Knap Hill) azalea cultivars

\begin{tabular}{|c|c|c|c|c|}
\hline Berryrose & $\mathrm{H}-1$ & pink & $4 / 3$ & June 17 \\
\hline *Brazil & $\mathrm{H}-1$ & orange & $4 / 3$ & June 17 \\
\hline Cathye Mayo & $\mathrm{H}-1$ & orange yellow & $4 / 4$ & June 12 \\
\hline Debutante & $\mathrm{H}-1$ & pink & $3 / 3$ & June 15 \\
\hline Devon & $\mathrm{H}-1$ & red & $3 / 3$ & June 22 \\
\hline *Fireball & $\mathrm{H}-\overline{1}$ & red & $3 / 3$ & June 19 \\
\hline *Gallipoli Red & $\mathrm{H}-1$ & red & $4 / 3$ & June 13 \\
\hline *Gibraltar & $\mathrm{H}-1$ & orange & $4 / 4$ & June 14 \\
\hline *Ginger & $\mathrm{H}-1$ & orange & $4 / 3$ & June 13 \\
\hline *Goldcrest & $\mathrm{H}-1$ & yellow & $4 / 4$ & June 12 \\
\hline Golden Dream & $\mathrm{H}-1$ & yellow & $3 / 3$ & June 10 \\
\hline *Gold Flake & $\mathrm{H}-1$ & yellow & $4 / 4$ & June 9 \\
\hline *Homebush & $\mathrm{H}-1$ & pink & $5 / 3$ & June 13 \\
\hline Kathleen & $\mathrm{H}-1$ & apricot & $3 / 3$ & June 18 \\
\hline Knaphill White & $\mathrm{H}-1$ & white & $4 / 4$ & June 20 \\
\hline Knaphill Red & $\mathrm{H}-1$ & red & $4 / 4$ & June 20 \\
\hline Marion Merriman & $\mathrm{H}-1$ & yellow & $4 / 3$ & June 12 \\
\hline * Old Gold & $\mathrm{H}-1$ & gold & $5 / 3$ & June 12 \\
\hline *Oxydol & $\mathrm{H}-1$ & white & $4 / 3$ & June 12 \\
\hline Persil & $\mathrm{H}-1$ & white & $3 / 3$ & June 17 \\
\hline *Princess Royal & $\mathrm{H}-1$ & white & $3 / 3$ & June 12 \\
\hline *Scarlet Pimpernel & $\mathrm{H}-1$ & scarlet & $3 / 3$ & June 20 \\
\hline *Silver Slippers & $\mathrm{H}-1$ & white & $4 / 4$ & June 18 \\
\hline *Sun Chariot & $\mathrm{H}-1$ & yellow & $4 / 4$ & June 16 \\
\hline Sweet Sue & $\mathrm{H}-1$ & pink & $4 / 4$ & June 12 \\
\hline *Sylphides & $\mathrm{H}-1$ & pink & $4 / 3$ & June 13 \\
\hline
\end{tabular}

${ }^{1}$ Hardiness rating method is that used by the American Rhododendron Society. H-1, hardy to $-32^{\circ} \mathrm{C} ; \mathrm{H}-2$, hardy to $-26^{\circ} \mathrm{C} ; \mathrm{H}-3$, hardy to $-21^{\circ} \mathrm{C}$.

"Quality rating method is that used by the American Rhododendron Society. $1=$ poor, $2=$ below average, 3 = average, $4=$ above average, $5=$ superior. A variety rated $4 / 2$ indicates above average bloom quality and below average plant type.

${ }^{3}$ Average date of full bloom at Kentville is a 5 -year average. 
Flower

Hardiness ${ }^{1}$ color

Average date ${ }^{3}$ of full bloom

Evergreen azalea cultivar

Mildred Mae

H-1 lavender

$3 / 4 \quad$ June 5

Minimum monthly temperatures, Kentville, N.S.

\begin{tabular}{lcccc} 
Year & $\begin{array}{c}\text { December } \\
{ }^{\circ} \mathrm{C}\end{array}$ & $\begin{array}{c}\text { January } \\
{ }^{\circ} \mathrm{C}\end{array}$ & $\begin{array}{c}\text { February } \\
{ }^{\circ} \mathrm{C}\end{array}$ & $\begin{array}{c}\text { March } \\
{ }^{\circ} \mathrm{C}\end{array}$ \\
\hline $1970-71$ & -23 & -24 & -27 & -12 \\
$1971-72$ & -18 & -23 & -23 & -17 \\
$1972-73$ & -20 & -18 & -23 & -18 \\
$1973-74$ & -16 & -23 & -21 & -16 \\
$1974-75$ & -13 & -22 & -22 & -18 \\
$1975-76$ & -22 & -23 & -18 & -13 \\
$1976-77$ & -18 & -22 & -15 & -8 \\
$1977-78$ & -21 & -20 & -21 & -19 \\
$1978-79$ & -18 & -20 & -23 & -15 \\
$1979-80$ & -21 & -19 & -17 & -20
\end{tabular}

\section{acknowledgments}

Mr. C. O. Gourley, Plant Pathology and Pesticide Residues Section of the Station, prepared the information on diseases. The section on insects was provided by Mr. C. J. S. Fox, Nova Scotia Department of Agriculture and Marketing, Kentville. 


\section{Acadia}

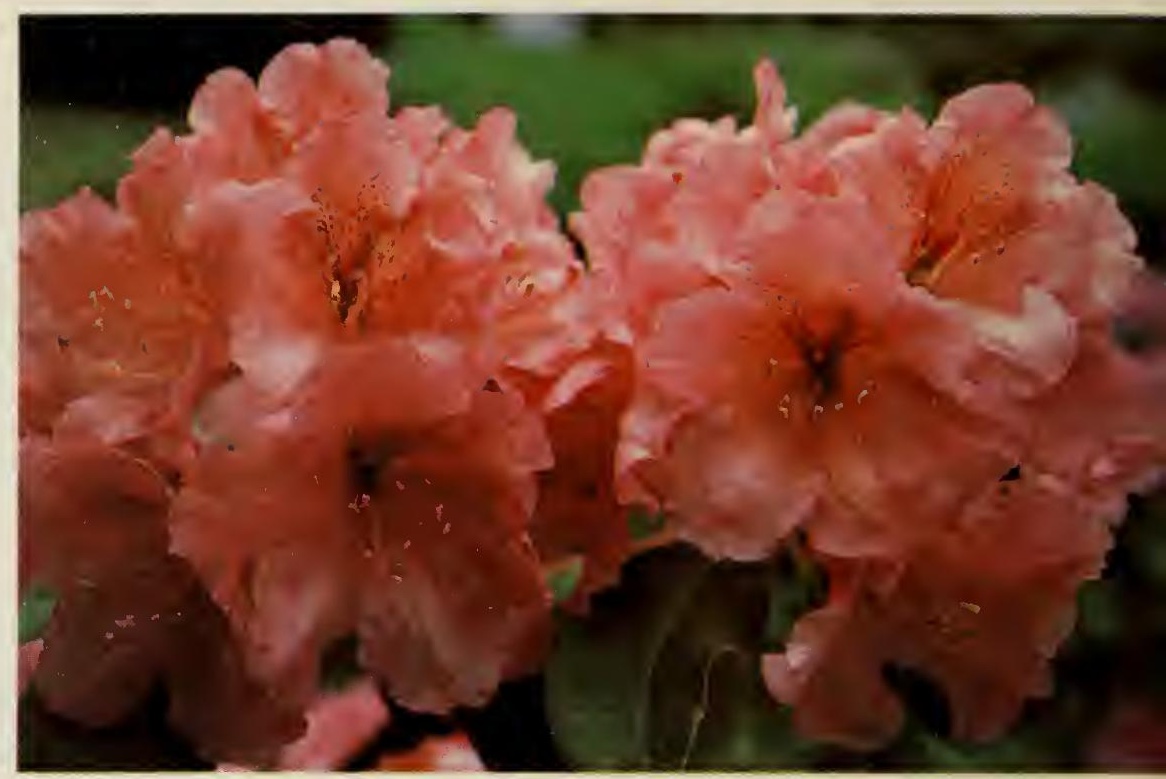

Ice Cube

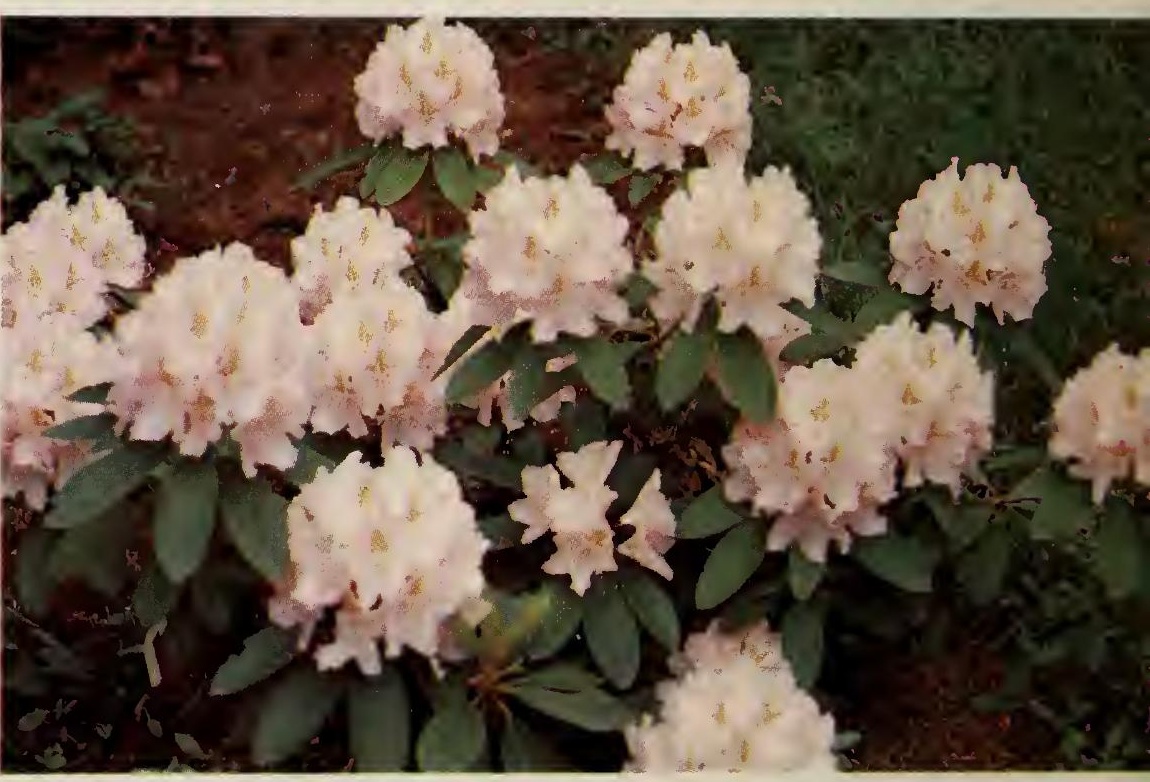

Ramapo

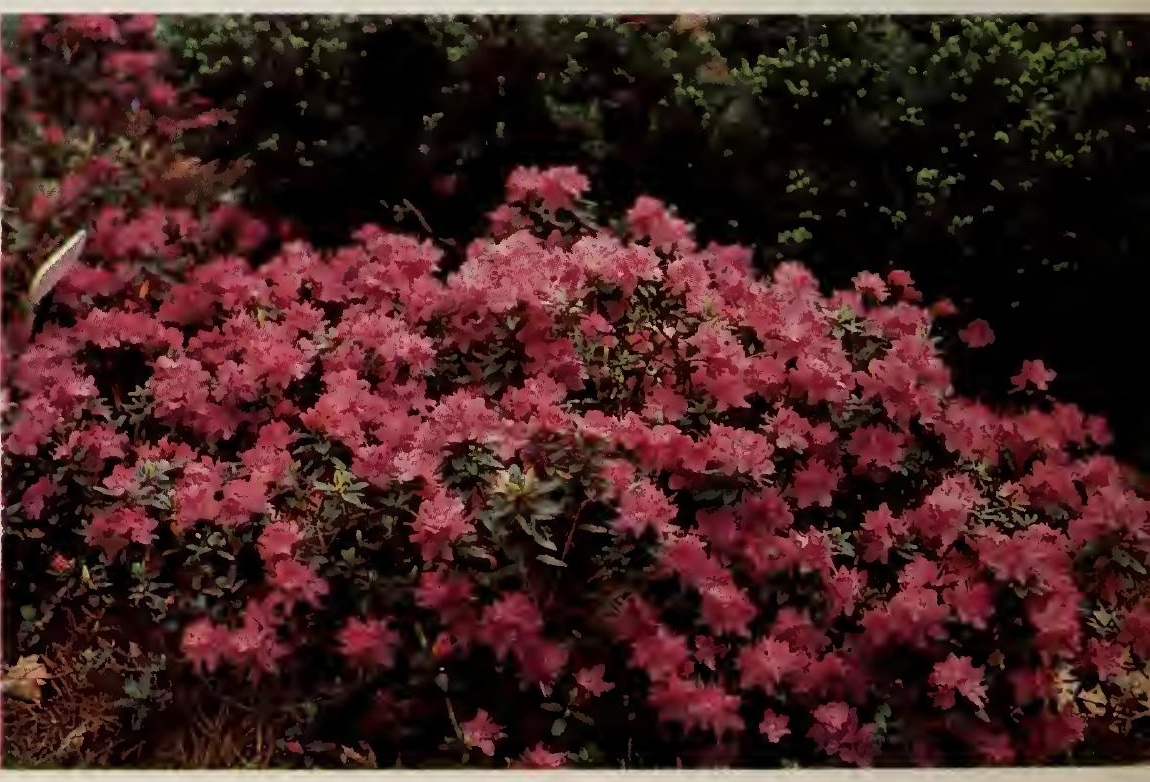

Figure 13. Some of the rhododendrons that have proved satisfactory at Kentville 


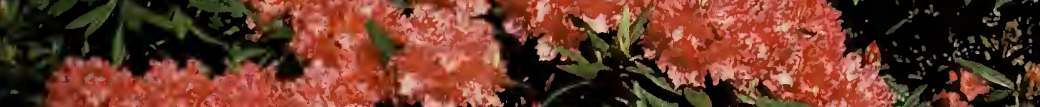

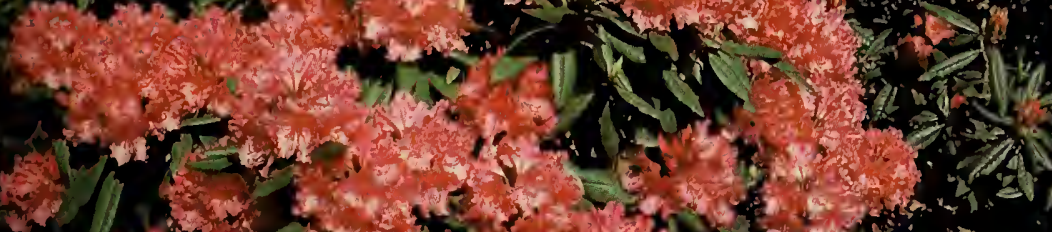

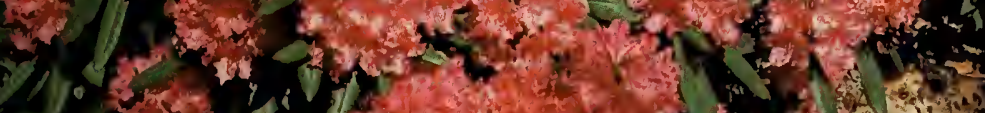

3
1

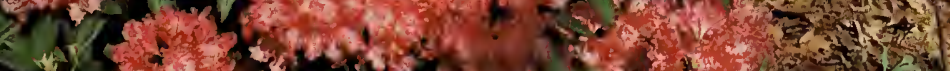

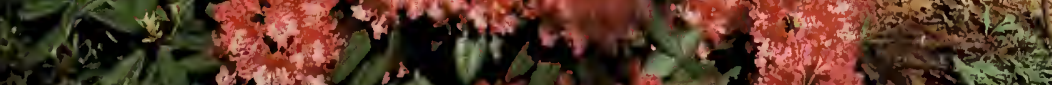
cond

(1)

Gabriel

tey

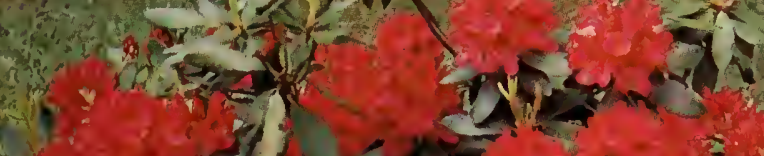

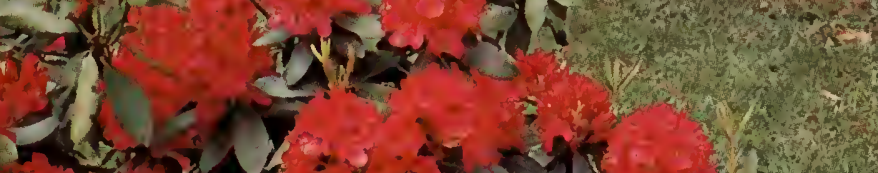

$x^{2} x^{2}+x^{2}+2$

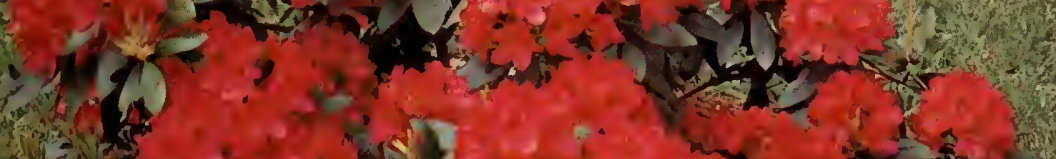

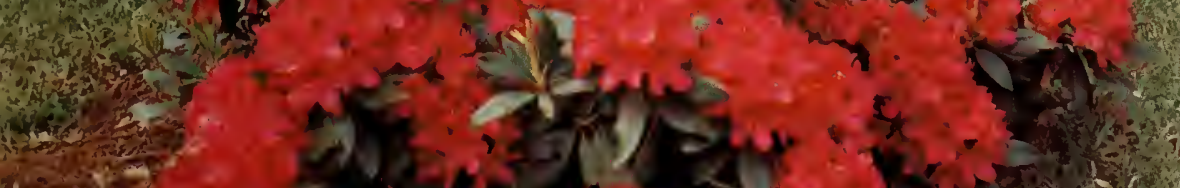

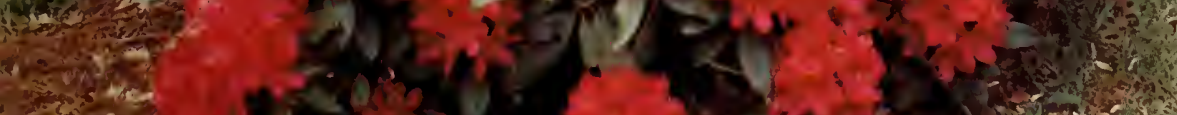

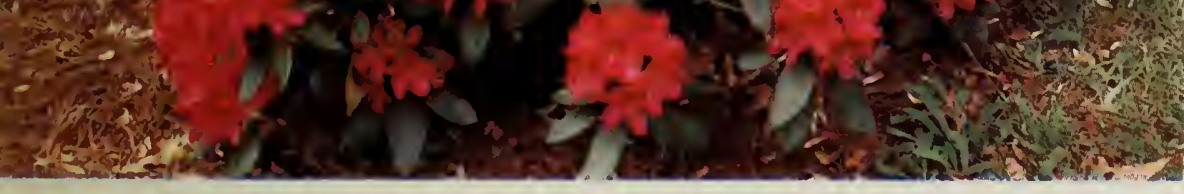

Nova Zembla

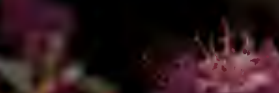

3 and 300

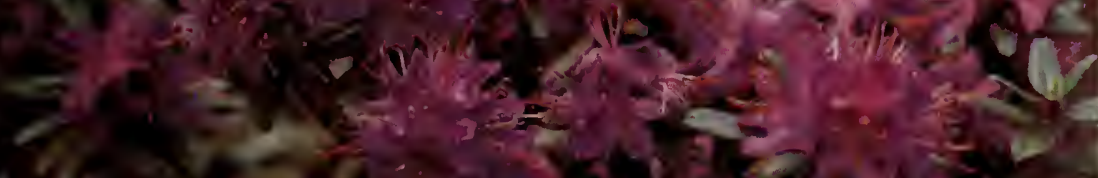

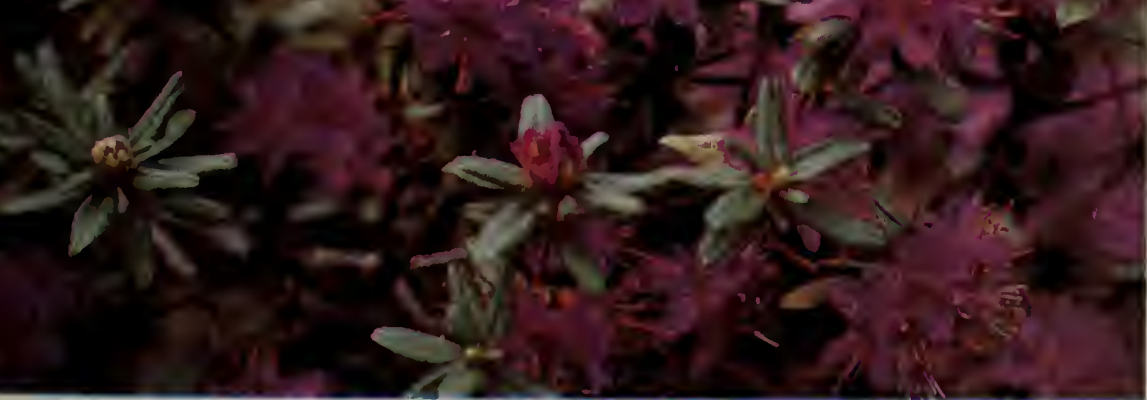

R. russatum 


\section{Satan}

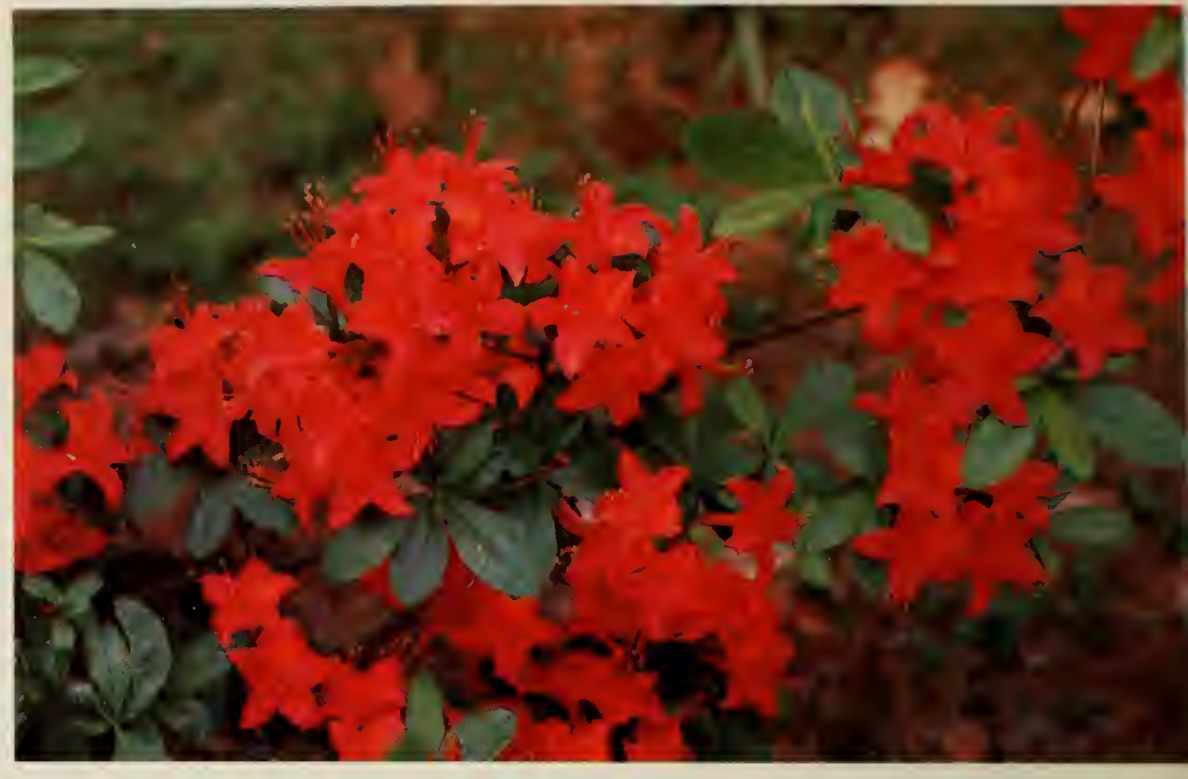

R. calendulaceum
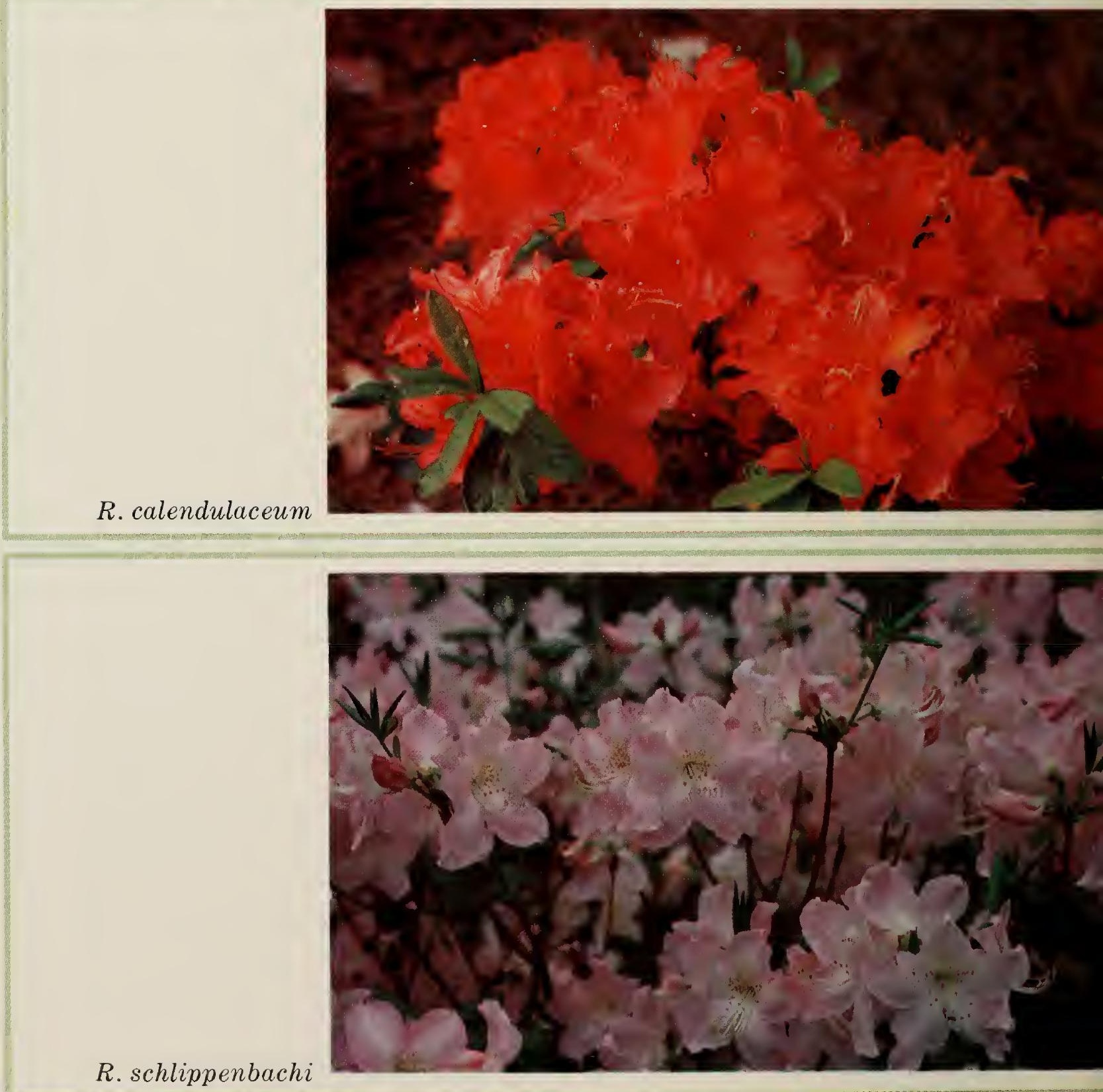

Figure 14. Examples of azaleas that have flowered well at Kentville 


\section{CONVERSION FACTORS FOR METRIC SYSTEM}

\begin{tabular}{|c|c|c|c|}
\hline Imperial units & $\begin{array}{l}\text { Approximate } \\
\text { onversion factor }\end{array}$ & \multicolumn{2}{|c|}{ Results in: } \\
\hline $\begin{array}{l}\text { LINEAR } \\
\text { inch } \\
\text { foot } \\
\text { yard } \\
\text { mile }\end{array}$ & $\begin{array}{l}\times 25 \\
\times 30 \\
\times 0.9 \\
\times 1.6\end{array}$ & $\begin{array}{r}\text { millimetre } \\
\text { centimetre } \\
\text { metre } \\
\text { kilometre }\end{array}$ & $\begin{array}{l}(\mathrm{mm}) \\
(\mathrm{cm}) \\
(\mathrm{m}) \\
(\mathrm{km})\end{array}$ \\
\hline $\begin{array}{l}\text { AREA } \\
\text { square inch } \\
\text { square foot } \\
\text { acre }\end{array}$ & $\begin{array}{l}\times 6.5 \\
\times 0.09 \\
\times 0.40\end{array}$ & $\begin{array}{r}\text { square centimetre } \\
\text { square metre } \\
\text { hectare }\end{array}$ & $\begin{array}{l}\left(\mathrm{cm}^{2}\right) \\
\left(\mathrm{m}^{2}\right) \\
(\mathrm{ha})\end{array}$ \\
\hline $\begin{array}{l}\text { VOLUME } \\
\text { cubic inch } \\
\text { cubic foot } \\
\text { cubic yard } \\
\text { fluid ounce } \\
\text { pint } \\
\text { quart } \\
\text { gallon } \\
\text { bushel }\end{array}$ & $\begin{array}{l}\times 16 \\
\times 28 \\
\times 0.8 \\
\times 28 \\
\times 0.57 \\
\times 1.1 \\
\times 4.5 \\
\times 0.36\end{array}$ & $\begin{array}{r}\text { cubic centimetre } \\
\text { cubic decimetre } \\
\text { cubic metre } \\
\text { millilitre } \\
\text { litre } \\
\text { litre } \\
\text { litre } \\
\text { hectolitre }\end{array}$ & $\begin{array}{l}\left(\mathrm{cm}^{3}\right) \\
\left(\mathbf{d m}^{3}\right) \\
\left(\mathrm{m}^{3}\right) \\
(\mathbf{m} \ell) \\
(\ell) \\
(\ell) \\
(\ell) \\
(\mathbf{h} \ell)\end{array}$ \\
\hline $\begin{array}{l}\text { WEIGHT } \\
\text { ounce } \\
\text { pound } \\
\text { short ton }(2000 \mathrm{lb})\end{array}$ & $\begin{array}{l}\times 28 \\
\times 0.45 \\
\times 0.9\end{array}$ & $\begin{array}{r}\text { gram } \\
\text { kilogram } \\
\text { tonne }\end{array}$ & $\begin{array}{l}(\mathrm{g}) \\
(\mathrm{kg}) \\
(\mathrm{t})\end{array}$ \\
\hline $\begin{array}{l}\text { TEMPERATURE } \\
\text { degree fahrenheit }\end{array}$ & $\begin{array}{l}{ }^{\circ} \mathrm{F}-32 \times 0.56 \\
\left(\text { or }{ }^{\circ} \mathrm{F}-32 \times 5 / 9\right)\end{array}$ & degree Celsius & $\left({ }^{\circ} \mathrm{C}\right)$ \\
\hline $\begin{array}{l}\text { PRESSURE } \\
\text { pounds per square ino }\end{array}$ & $\operatorname{ch} \times 6.9$ & kilopascal & (kPa) \\
\hline $\begin{array}{l}\text { POWER } \\
\text { horsepower }\end{array}$ & $\begin{array}{l}\times 746 \\
\times 0.75\end{array}$ & $\begin{array}{r}\text { watt } \\
\text { kilowatt }\end{array}$ & $\begin{array}{l}(W) \\
(\mathbf{k W})\end{array}$ \\
\hline $\begin{array}{l}\text { SPEED } \\
\text { feet per second } \\
\text { miles per hour }\end{array}$ & $\begin{array}{l}\times 0.30 \\
\times 1.6\end{array}$ & $\begin{array}{l}\text { metres per second } \\
\text { kilometres per hour }\end{array}$ & $\begin{array}{l}(\mathrm{m} / \mathrm{s}) \\
(\mathrm{km} / \mathrm{h})\end{array}$ \\
\hline $\begin{array}{l}\text { AGRICULTURE } \\
\text { bushels per acre } \\
\text { gallons per acre } \\
\text { quarts per acre } \\
\text { pints per acre } \\
\text { fluid ounces per acre } \\
\text { tons per acre } \\
\text { pounds per acre } \\
\text { ounces per acre } \\
\text { plants per acre }\end{array}$ & $\begin{array}{l}\times 0.90 \\
\times 11.23 \\
\times 2.8 \\
\times 1.4 \\
\times 70 \\
\times 2.24 \\
\times 1.12 \\
\times 70 \\
\times 2.47\end{array}$ & $\begin{array}{l}\text { ectolitres per hectare } \\
\text { litres per hectare } \\
\text { litres per hectare } \\
\text { litres per hectare } \\
\text { millilitres per hectare } \\
\text { tonnes per hectare } \\
\text { cilograms per hectare } \\
\text { grams per hectare } \\
\text { plants per hectare }\end{array}$ & $\begin{array}{l}\text { (h } \ell / h a) \\
(\ell / h a) \\
(\ell / h a) \\
(\ell / h a) \\
\text { (m/l/ha) } \\
\text { (t/ha) } \\
\text { (kg/ha) } \\
\text { (g/ha) } \\
\text { (plants/ha }\end{array}$ \\
\hline
\end{tabular}

Examples: 2 miles $\times 1.6=3.2 \mathrm{~km} ; 15 \mathrm{bu} / \mathrm{ac} \times 0.90=13.5 \mathrm{~h} / \mathrm{ha}$ 


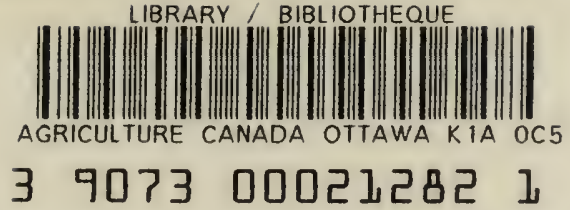


